\title{
Heavy rainfall episodes over Liguria in autumn 2011: numerical forecasting experiments
}

\author{
A. Buzzi, S. Davolio, P. Malguzzi, O. Drofa, and D. Mastrangelo \\ Institute for Atmospheric Sciences and Climate CNR-ISAC, Bologna, Italy \\ Correspondence to: A. Buzzi (a.buzzi@isac.cnr.it)
}

Received: 13 November 2013 - Published in Nat. Hazards Earth Syst. Sci. Discuss.: 5 December 2013

Revised: 8 April 2014 - Accepted: 8 April 2014 - Published: 26 May 2014

\begin{abstract}
The Liguria coastal region in Italy was affected by two heavy rainfall episodes and subsequent severe flooding that occurred at the end of October and the beginning of November 2011. In both cases, the very large accumulated precipitation maxima were associated with intense and quasi-stationary convective systems that developed near the coast, both related to orographic lift and similar low-level mesoscale flow patterns over the Ligurian Sea, giving rise to pronounced convergence lines.

This study aims at analysing the main dynamical processes responsible for the onset, lifecycle, intensity and localisation/propagation of the precipitating systems, using the ISAC convection-permitting model MOLOCH applied at different spatial resolutions and comparing model output fields with available observations. The ability of the model in quantitative precipitation forecasting (QPF) is tested with respect to initial conditions and model horizontal resolution. Although precipitation maxima remain underestimated in the model experiments, it is shown that errors in QPF in both amount and position tend to decrease with increasing grid resolution.

It is shown that model accuracy in forecasting rainfall amounts and localisation of the precipitating systems critically depends on the ability to represent the cold air outflow from the Po Valley to the Ligurian Sea, which determines the position and intensity of the mesoscale convergence lines over the sea. Such convergence lines controls, together with the lifting produced by the Apennines chain surrounding the coast, the onset of the severe convection.
\end{abstract}

\section{Introduction}

Flood forecasting remains a very difficult task, depending on many factors that pertain to meteorological and hydrological sciences and practices. In this paper we deal only with the meteorological component, for which the critical objective is the accuracy of quantitative precipitation forecasting (QPF). An accurate, in space and time, QPF is an obvious pre-requisite for attempting very short to short-range (from a few hours to one day) forecasting of floods in small or very small river catchments (of the order of $10^{3} \mathrm{~km}^{2}$ or less), for which direct rainfall and river flow observations are not very useful as input to hydrological forecasting models. Here we address mainly the problem of flash floods, namely floods in relatively small basins that are the consequence of very high precipitation rates persisting for hours over the same area.

The case studies we have chosen are two severe flood episodes, which both occurred during autumn 2011 in the Liguria (geographical and administrative) region in Italy, namely the "Cinque Terre flood" (25 October 2011) and the "Genoa flood" (4 November 2011). Geographic locations are reported in Fig. 1. Liguria is a coastal area prone to severe floods, especially during autumn. Flood episodes are associated with a number of topographical (relatively steep though not high slopes, a concave arc-shaped coastline, and short torrents/rivers having very small catchments, of the order of $10^{2} \mathrm{~km}^{2}$ or even smaller) and meteorological-climatological factors, namely a coastal slope exposed to moist southerly flows having the character of "warm conveyor belts" (Carlson, 1980; Bertò et al., 2005) or "atmospheric rivers" (Ralph and Dettinger, 2011), important sensible and latent fluxes from the sea (Turato et al., 2004) and the formation of convective systems. The latter factors are in turn often associated with cyclonic disturbances propagating from the Atlantic to 

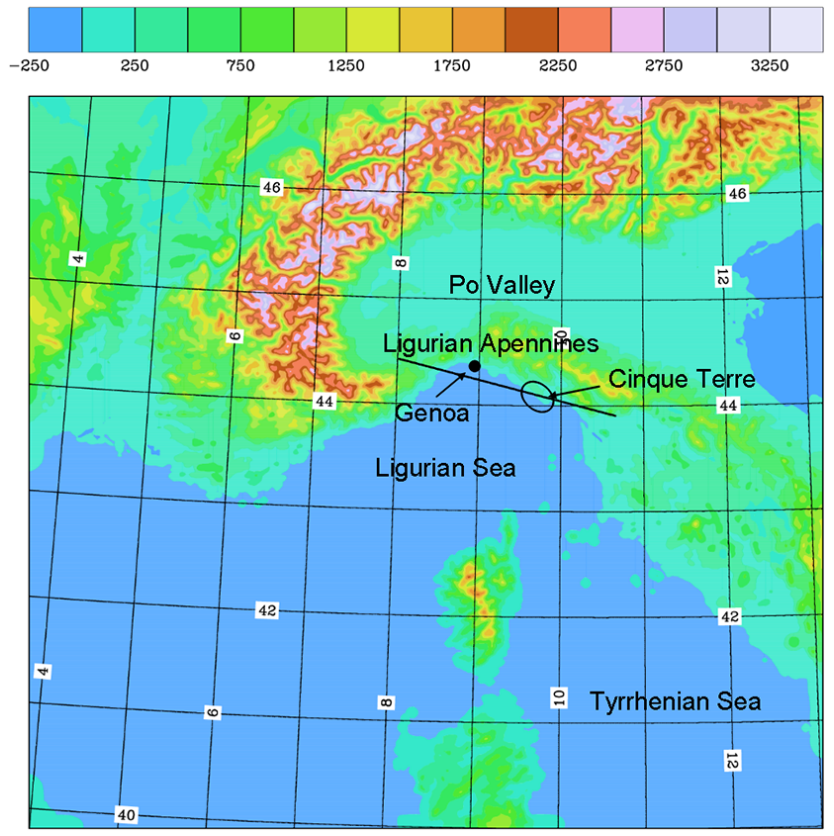

Figure 1. Integration domain of the MOLOCH experiments. The black line marks the cross-section location of Fig. 11. Geographical names are indicated. Colours represent the orography according to the associated scale. Parallels and meridians are drawn every $1^{\circ}$.

the Mediterranean or originating/reinvigorating in the area of the Gulf of Genoa and surroundings, due to orographically induced cyclogenesis (Tibaldi et al., 1990). In the episodes considered here, as well as in other similar circumstances of severe floods in the same area, a concurrence of multiscale meteorological factors, from the synoptic-scale circulation to the meso-alpha and meso-beta scale flows associated with fronts and local orographic effects, contribute to determine precipitation amounts, localisation, and timing. Particular attention must be given to the conditions that favour the persistence of torrential rain in the same area. Such conditions are related to both large- (i.e. propagation speed of synoptic circulation patterns) and small-scale processes (i.e. convective-scale auto-organisation), including intermediate scales characterising local frontal/density current dynamics, as will be shown and discussed below. The largescale characteristics, as the presence of a large amplitude incoming trough, characterised by an upper-level potential vorticity maximum and preceded by a strong meridional flow at low levels and southwesterly flow at higher levels, are known to represent a necessary but not sufficient condition for heavy rain occurrence in the area considered. For this reason it is important that the large-scale processes are well simulated/predicted by models for an accurate QPF. Failing some aspects of the synoptic-scale forecast negatively affects QPF, but, conversely, good large-scale forecasting is not sufficient for an accurate QPF involving mesoscale processes like convection and orographic forcing.
Although we have chosen here two cases considered to be representative of a class of phenomena typical of the specific geographical area, it is known that other areas of the Mediterranean, as well as the world, are prone to similar events (Nuissier et al., 2008; Ricard et al., 2012; Ramis et al., 2009). The coastal areas characterised by orography, no matter if immediately near the coast or at some distance inland, can be affected by heavy rain episodes in which orographic precipitation enhancement, combined with atmospheric organised convection, may produce accumulated precipitation values exceeding $500 \mathrm{~mm}$ in less than 24 or even $12 \mathrm{~h}$. A number of international research projects have been devoted to studying such processes, the last of which is HyMeX (Hydrological Cycle in Mediterranean Experiment, Drobinski et al., 2014 - see also http://www.hymex.org), whose first special observation period (SOP 1) took place in autumn 2012 over the western Mediterranean basin, including Liguria as one of the hydro-meteorological sites of interest (Ducrocq et al., 2014). By targeting our investigation on this type of event, we exclude, on one side, the more predictable "largescale" floods due to long-lasting rainfall episodes affecting wide basins, and, on the other side, the almost unpredictable (unless with nowcasting tools) local flash floods mainly due to individual thunderstorms. The latter category has to do with the chaotic behaviour associated with very rapid conditional instability, for which intrinsic predictability does not exceed the timescale of the order of tens of minutes. A clearcut separation, from the point of view of basic dynamic meteorology, between the type of somehow organised processes associated with the precipitating systems we are considering here and the purely random convection is not feasible, since chaotic convective dynamics act also in our cases to limit the QPF. Nevertheless, we will try to spot key mesoscale circulation aspects that, controlling convection and possibly triggering multi-scale feedback processes, account for the predictability margins that seem to emerge from the practice and experimentation of numerical weather prediction models.

The purpose of this paper is twofold. On the applicative side, we address the problem of testing, in each case, the ability of the model to predict precipitation quantitatively, using state-of-the-art meteorological forecasting models, considering in particular the effects of horizontal grid spacing. On the more speculative side, we try to understand, with the aid of our models and by comparing model outputs with observations, the characteristics of the meteorological circulation patterns that play a role in controlling the precipitating systems and their predictability.

The starting stimulus of this research derived from noting that the actual numerical forecasts made in real time with high-resolution models provided some useful guidance to the forecasters, although with substantial errors in precipitation amount (general underestimation of accumulated values) and localisation, depending also on the initial time of the forecasts. (Incidentally, the BOLAM and MOLOCH model system was, and is, used by the Liguria regional environmental 
service ARPAL - see http://www.arpal.gov.it). Actually, useful forecasts were issued only on the basis of the 00:00 UTC analyses of the same day, allowing for no more than a few hours of actual forecast lead time (we shall also consider this aspect in the course of this paper).

The paper is organised as follows. Section 2 reports a description of synoptic and mesoscale features of both episodes. Section 3 briefly describes the numerical models employed in this study and the setup of the experiments. Section 4 illustrates the QPF obtained both from BOLAM (the driving model) and MOLOCH simulations with different initial and boundary conditions and horizontal resolution. In Sect. 5, some model diagnostics are presented. The summary and conclusions are reported in Sect. 6 .

\section{The episodes}

Both events (the Cinque Terre episode, hereafter CT, and the Genoa episode, hereafter GE) were characterised by extensive damages and casualties, mainly due to the flash flooding of small rivers affecting villages (the CT case) and part of the city of Genoa (the GE case). Floods were also associated with landslides and debris flow (Marchi et al., 2013). The meteorological cause was heavy rainfall, whose maxima, as observed at specific stations, exceeded $450 \mathrm{~mm}$ in less than $12 \mathrm{~h}$ in both cases. Although the rain gauge network in the area is relatively dense, having a separation distance of about $40 \mathrm{~km}^{2}$ (Rebora et al., 2013, hereafter Retal), the observed high variability, typical of convective precipitation, suggests that accumulated values may have reached $500 \mathrm{~mm}$. A detailed description and characterisation of the hydro-meteorological observations and processes is provided in Retal, to which the reader is referred for details including meteorological synoptic and mesoscale analyses, rainfall data and elements of social impact. More specific hydrological aspects are also presented in Silvestro et al. (2012), while technical reports for both episodes are available from ARPAL (www address above). Figures 2 and 3 show the rain gauge observations of precipitation, accumulated over $24 \mathrm{~h}$.

Before considering what appear to be the most significant differences between the two cases, we examine here the analogies. On the large/synoptic scale, in both cases the following aspects have been documented:

- a slowly advancing Atlantic upper level trough over western Europe and the western Mediterranean, with an associated low-level main depression centred near Ireland and forming a secondary low over the Gulf of Lion. The upper-level flow over the Ligurian Sea was diffluent and southwesterly, favouring mean upward motion. In both cases, the cold front was located over the western Mediterranean, that is to the west of the most intense precipitation. Therefore, the flood-producing rainfall was mainly pre-frontal;
- an upper positive anomaly of potential vorticity (PV), slowly propagating southeastward toward the Gulf of Lion;

- a low-level anticyclone, corresponding to an upper-level ridge, over eastern Europe;

- the presence of convective available potential energy (CAPE) over the Mediterranean embedded in a meridional flow with a rather large shear, where winds were southeasterly near the surface and southwesterly in the middle-upper troposphere. The low-level wind shear was more pronounced over the eastern part of the Ligurian Sea.

However, the mesoscale temperature and wind distribution at low levels were complex, mainly characterised by large gradients associated with orographically induced flows. On the meso scale, two main low-level currents were identified in both cases over the area surrounding the Liguria region: (1) a warm and moist southeasterly low-level jet, channelled between Corsica and Central Italy and impinging over the Ligurian Apennines, mainly on the eastern side; (2) a northerly shallow cold flow, corresponding to an outflow of pre-existing cold air from the Po Valley to the north of the Apennines (Fig. 1), affecting the western part of Liguria.

The cold flow over the sea, which propagates as a density current, appears to be induced by an easterly inflow into the Po Valley from the Adriatic side, possibly enhanced by the upstream deviating effect of the Alps ("barrier wind"). The presence of a ridge in the mean sea level pressure over the Po Valley is a typical signature of this situation, in which the Po Valley acts as a sort of reservoir of cold air that is forced to flow out of the lowest gap in the surrounding orography, over the central part of Liguria, in cases when the flow is easterly or even southeasterly at the northern Adriatic outlet. The Advanced Scatterometer (ASCAT) sea surface wind data reported in Figs. 4 and 13 (for the two episodes, respectively) of Retal illustrate the complex wind pattern near the surface and support the above description. The cited figures show clearly the clockwise (anticyclonic) deviation of the cold air that, after descending the coastal Apennines slope and accelerating over the Ligurian Sea, tends to follow the Cote d'Azur profile, surrounding the orographic tip constituted by the Maritime Alps. However, on the eastern side this cold air tends to converge with the southeasterly warm flow, wedging itself below it and favouring uplift where convection is triggered. We will show below how the above picture of the mesoscale circulation is adequately represented by high-resolution models and how it interacts with convective systems.

The smallest scales detected in both episodes concern the cloud and precipitation organisation. Even if time averages of a few hours are applied, as in the case of accumulated precipitation measured by rain gauges or radar reflectivity integrals (Figs. 6 and 14 of Retal), space and time variability reveal the 


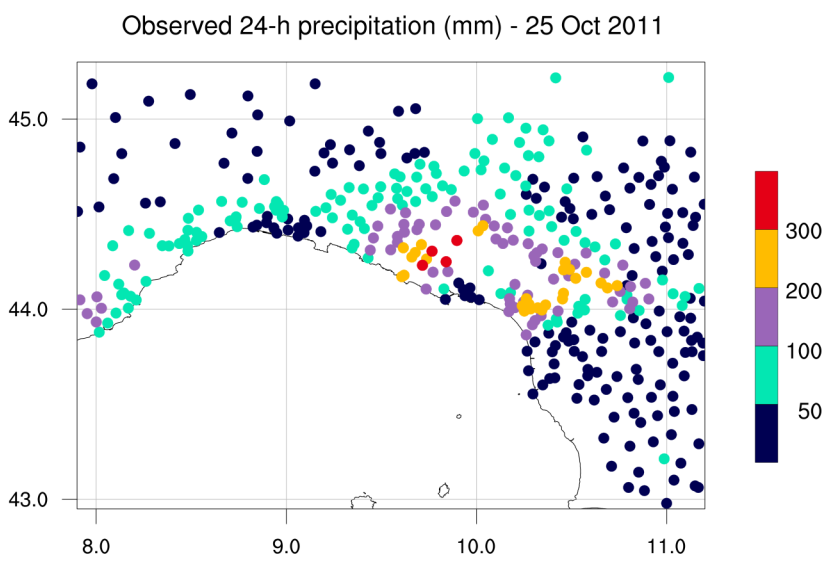

Figure 2. Observed precipitation accumulated in the $24 \mathrm{~h}$ period starting at 00:00 UTC of 25 October 2011. Parallels and meridians are drawn every $1^{\circ}$.

convective, therefore partly chaotic, nature of the precipitating systems. More detailed investigation of the cloud properties from satellite observations (see also Davolio et al., 2012), radar-estimated instantaneous precipitation (Fig. 5 of Retal), and accumulated rainfall distribution (Figs. 2 and 3), indicates that the convective systems were not stationary, with different cells being regenerated over the sea and moving repeatedly over the same area to contribute to the exceptionally large rainfall. In the GE case, the most intense rain patterns were observed to swing in the area east of Genoa, before moving more steadily to the west in the final stage. In such a situation, it is somehow surprising that accumulated precipitation exhibits some degree of predictability.

There are important differences between the two cases, in both the synoptic and mesoscale patterns. For instance, the trough axis orientation in the CT case was NW-SE, while in the GE case it was more meridionally aligned (see Fig. 21 of Retal). The cold front in the CT case moved more rapidly, affecting to some extent the precipitation area in the latest hours of the event. The conditional instability over the Ligurian Sea, where convection was initiated, was definitely larger in the CT than in the GE case, according to both ECMWF-IFS and NOAA-GFS analyses. Moreover, the lowlevel temperature gradient between the cold Po Valley and the warm flow sector over the Ligurian Sea was about $30 \%$ larger in the CT case (horizontal difference $\Delta T$ of about $\left.12^{\circ} \mathrm{C}\right)$ than in the GE case $\left(\Delta T\right.$ of about $\left.8^{\circ} \mathrm{C}\right)$. In the former CT case, in fact, the portion of the Ligurian Sea affected by the cold outflow was much wider, in the W-E direction, than in the former (compare Figs. 4 and 13 of Retal). This is clearly associated with a more eastward position of the heavy rain-producing convective system in the former case (compare Figs. 2 and 3 of this paper).

In the GE case, the most intense precipitation was always associated with the line of convergence between the cold, northerly outflow and the southeasterly flow at low levels.

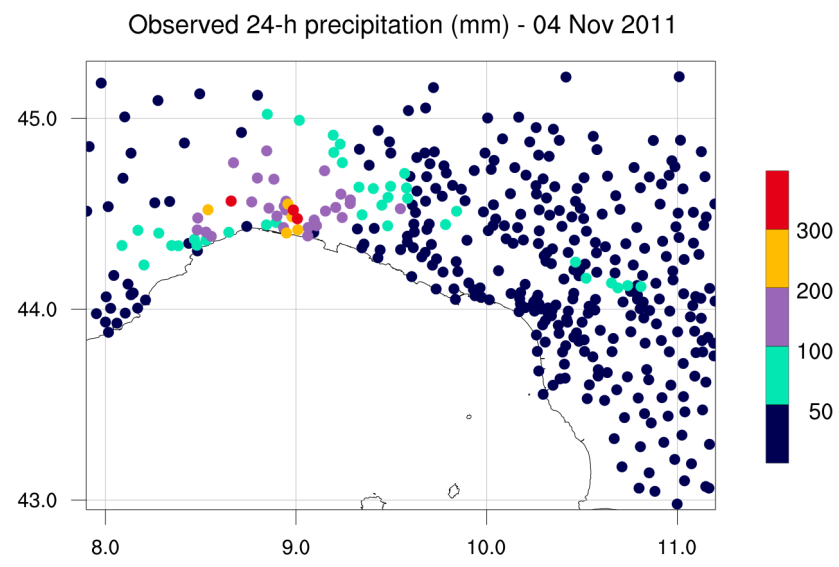

Figure 3. Observed precipitation accumulated in the $24 \mathrm{~h}$ period starting at 00:00 UTC of 4 November 2011. Parallels and meridians are drawn every $1^{\circ}$.

The most intense rain patterns were observed to oscillate in the area east of Genoa, before moving more steadily to the west in the final stage. It will be shown below that the relatively high degree of predictability of this event is due to the model's capability of correctly predicting the position of this mesoscale convergence line. The model's horizontal grid spacing is a key parameter in this case.

The CT event is more complex, as indicated by the numerical experiments described in Sect. 5. Figure 4 shows a radar reflectivity field that is representative of the rainfall pattern of the CT case. Also in this event, the convergence line acted as a trigger of convection, but with different cells being regenerated and moving occasionally over the same area to contribute to the exceptionally large rainfall. The most intense rainbands, responsible for the coastal slides in the Cinque Terre region and inland floods, developed during the central hours of 25 October and were associated with convective cells triggered upstream over the Ligurian Sea. The numerical results presented below indicate that the trigger mechanism provided by the convergence line accounts for the somewhat extended range of predictability, with respect to purely free convection, of this event.

\section{Models and experimental setup}

Two different models are employed in cascade for the simulation experiments described below. Since the main purpose of this work is to investigate the QPF degree achievable in a model configuration that mimics the operational mode (as those currently employed at both ISAC - see http://www.isac.cnr.it/dinamica/projects/forecasts/ - and ARPAL - see http://www.arpal.gov.it/index.php? option=com_flexicontent $\backslash \&$ view $=$ items $\backslash \&$ cid $=56 \backslash \& i d=180 \backslash$ \&Itemid=218), we have used the same model chain, constituted by ISAC meteorological models BOLAM (hydrostatic) 


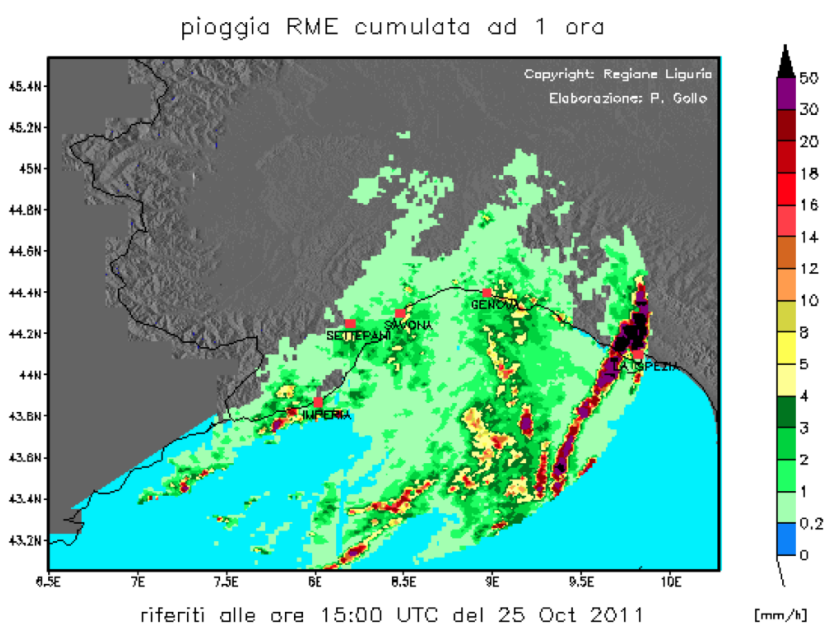

Figure 4. Radar reflectivity, 15:00 UTC of 25 October 2011 (courtesy of Regione Liguria). Latitudes and longitudes are indicated on the left and bottom axes, respectively.

and MOLOCH (non hydrostatic), starting from global model (NOAA-GFS and ECMWF-IFS) analyses and forecasts used to define initial and lateral boundary condition of the outer (BOLAM) domain. Since the above global forecast data are available, at best, every three hours, the BOLAM model is employed to provide the lateral boundary conditions for the inner grid of the MOLOCH model at $1 \mathrm{~h}$ intervals. This current practice has proved to be reliable and economical in bridging the gap between the "coarse" global model fields $\left(0.5^{\circ}\right.$ for the NOAA-GFS data and about $0.20^{\circ}$ for the ECMWF data) and the high-resolution forecast.

The BOLAM and MOLOCH models differ mainly in the dynamical core, including a different vertical coordinate discretisation, and by the fact that BOLAM includes the KainFritsch (using a modified version based on Kain, 2004) convective parameterisation scheme, while in MOLOCH a simple shallow convection scheme is applied. In fact, in the range of horizontal grid spacing of $1-3 \mathrm{~km}$ for which MOLOCH is designed, it is assumed that deep convection can be explicitly simulated while shallow convection remains mainly a subgrid process. Atmospheric radiation, atmospheric boundary layer and surface layer parameterisations, soil processes and, to a large extent, microphysical processes are common in the two models.

The most relevant results are derived from the MOLOCH model output. Therefore, they will be considered in more detail in this paper, although some considerations of the BOLAM QPF results will also be provided. Considering that the results discussed here mostly depend on the MOLOCH properties (although it has been verified that some characteristics of the outer BOLAM grid can affect the small-scale properties of the development and evolution of convection as simulated in the MOLOCH inner grid), a very synthetic description of the sole MOLOCH model is provided below. For a description of BOLAM and its coupling with MOLOCH, see also Buzzi et al. (1994, 2003), Malguzzi et al. (2006), and Davolio et al. (2006).

\subsection{Model dynamics}

MOLOCH is a non-hydrostatic, fully compressible, convection permitting model developed at ISAC. It integrates the set of atmospheric equations with prognostic variables: pressure, absolute temperature, specific humidity, horizontal and vertical components of velocity, turbulent kinetic energy and five water species, represented on the latitude-longitude, rotated Arakawa C-grid.

A hybrid terrain-following coordinate, depending on air density and relaxing smoothly to horizontal surfaces away from the Earth's surface, is employed (Davolio et al., 2006). Time integration is based on an implicit scheme for the vertical propagation of sound waves, while explicit, time-split schemes are implemented for integration of the remaining terms of the equations of motion. Three-dimensional advection is computed using the Eulerian weighted average flux scheme (Billet and Toro, 1997).

\subsection{Model physics}

The atmospheric radiation is computed with a combined application of the RG (Ritter and Geleyn, 1992) scheme and the ECMWF scheme, employing 14 channels for the infrared and visible bands (Mlawer et al., 1997; Morcrette et al., 2008). Since the ECMWF scheme is much more computationally expensive than the RG scheme, and hence could not be applied to each time step and in each grid column, it is used at alternate grid points and at long intervals to compute corrections to the RG scheme, the latter being used at all grid points and in rapid update mode. Cloud fraction (used as input for radiation schemes) is computed as a function of explicit cloud variables (liquid and solid), relative humidity and local dry and moist stability parameters.

The microphysical scheme was initially based on the parameterisation proposed by Drofa and Malguzzi (2004), with successive upgrades. The spectral properties of hydrometeors are simulated assuming a generalised gamma function distribution. The presently applied scheme describes the following processes: nucleation of cloud water $(\mathrm{cw})$ and cloud ice (ci), condensation and evaporation of $\mathrm{cw}$, freezing of $\mathrm{cw}$, nucleation, sublimation and melting of ci, auto-conversion of cw and of ci, sublimation of snow and graupel, collection/accretion/riming involving thirteen different hydrometeor interaction processes, melting and evaporation of hydrometeors, computation of terminal fall speeds and fall processes, using a conservative-diffusive backward-upstream integration scheme. Temperature is updated by imposing exact enthalpy conservation at constant pressure. The MOLOCH microphysical scheme has the capability of describing the two-moment microphysics, by integrating in time the spatial 
distribution of the number density of $\mathrm{cw}$ and ci describing the cloud spectra evolution. However, in the present paper the one-moment option is applied.

The turbulence parameterisation scheme is based on a turbulent kinetic energy mixing length $(E-l)$ closure theory of order 1.5, where the turbulent kinetic energy equation (including advection) is evaluated (Zampieri et al., 2005). Surface turbulent fluxes of momentum, specific humidity and temperature are computed by the classical MoninObukhov theory with Businger/Holtslag functions in the unstable/stable case. The mixing length is computed from turbulent kinetic energy (Deardorff, 1980) in the stable atmosphere and from Bougeault and Lacarrere (1989), modified by Zampieri (2004), in the unstable environment. Over the sea, a Charnock (1955) roughness is introduced, which takes into account the wave height as a function of the surface wind speed. The sea surface temperature (SST) is computed, depending on latent and sensible heat fluxes and radiative fluxes, using a simple slab ocean model in which the analysed distribution of SST represents a relaxation reference value.

The soil model of MOLOCH, similar to that of BOLAM, uses seven layers, whose depths increase moving downward. The soil model computes surface energy, momentum, water and snow balances, heat and water vertical transfer, vegetation effects at the surface (evapo-transpiration, interception of precipitation, wilting, etc.) and in the soil (extraction of water by roots). It takes into account the observed geographical distribution of different soil types and soil physical parameters. The soil model also includes treatment of water freezing and melting processes within the ground. Skin temperature is obtained by imposing heat flux balance at the soil-atmosphere interface.

Validation, inter-comparisons and applications of the MOLOCH model to case studies of severe weather and heavy precipitation can be found in Malguzzi et al. (2006), Richard et al. (2007), Diomede et al. (2008), Davolio et al. (2009a, b), Rotach et al. (2009), and Fantini et al. (2012).

\subsection{Experimental setup}

The experiments discussed below have been based on both NOAA-GFS and ECMWF-IFS global analyses valid at 12:00 UTC of the day preceding the flood (24 October and 3 November 2011, respectively) and 00:00 UTC of the same day (25 October and 4 November 2011, respectively) of each event. The BOLAM intermediate integrations have been made over a large domain comprising the eastern Atlantic, most of Europe and part of North Africa (the same area of the ISAC experimental daily forecast mentioned above), on a rotated grid, centred at $43.5^{\circ} \mathrm{N}, 10.5^{\circ} \mathrm{E}$, composed of $418 \times 290$ points (longitude-latitude) at $0.1^{\circ}$ spacing, with 50 atmospheric levels and 7 soil layers. The MOLOCH experiments have been performed at variable resolutions, in the range $1-3 \mathrm{~km}$ of grid spacing, with 50 levels, on an area centred over the Ligurian Sea and extending for $7^{\circ}$ in both latitude and longitude in the rotated coordinate system, corresponding to a domain of about $780 \times 780 \mathrm{~km}$ (Fig. 1). This domain is considered to be large enough to control the spurious effects of lateral boundary conditions and to permit explicit convection to develop freely in unstable flow. MOLOCH runs have been initiated at different times even when embedded in the same BOLAM forecast, in order to test the effect of relatively small changes in the initial condition. Starting the MOLOCH integration at the same instant of the global model analysis would imply, however, an effective sudden reduction in grid resolution (instantaneous nondynamical downscaling, i.e. made by pure interpolation) by a factor from 10 to 40 . This ratio seems excessive for a correct meteorological model nesting, especially in the presence of steep orography. On the other hand, starting MOLOCH after a BOLAM integration of several hours implies that the BOLAM integration, although providing intermediate resolution, may introduce additional errors in the forecast trajectory, due, for example, to the convective parameterisation. For both episodes, considering that the severe convective precipitation along the Ligurian coast began early in the morning (between 01:00 and 03:00 UTC in the GE case and between 07:00 and 09:00 UTC in the CT case), and lasted for a period of more than $12 \mathrm{~h}$ (in both cases the highest precipitation period was observed around mid-day), the MOLOCH run experiments have been conducted for intervals between 12 and $24 \mathrm{~h}$, when the 00:00 UTC analyses of the same day were used. Longer preliminary runs have been performed for the case of initial conditions provided by 12:00 UTC analyses. However, since in this case QPF results were less realistic, such experiments are only briefly accounted in the following section.

\section{Results regarding QPF}

\subsection{BOLAM model results}

Before analysing the results of explicit convection in the context of non-hydrostatic simulations, it is interesting to consider briefly what the BOLAM model would predict in terms of QPF and the partition of stratiform versus convective precipitation. Figure 5 shows, for reference, the distribution of total (stratiform + convective) BOLAM precipitation, accumulated during the entire day of 25 October 2011, using both ECMWF-IFS and NOAA-GFS at two different analysis times, namely 12:00 UTC of 24 October and 00:00 UTC of 25 October. The general distribution of precipitation over the eastern Liguria region appears similar, especially for what concerns the position of the relative maxima over the Cinque Terre to the east of Genoa. Secondary precipitation maxima also appear just to the east (over northern Tuscany), over the Maritime Alps and the Eastern Alps. 
a

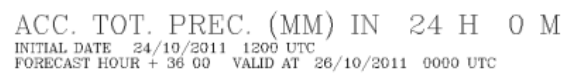

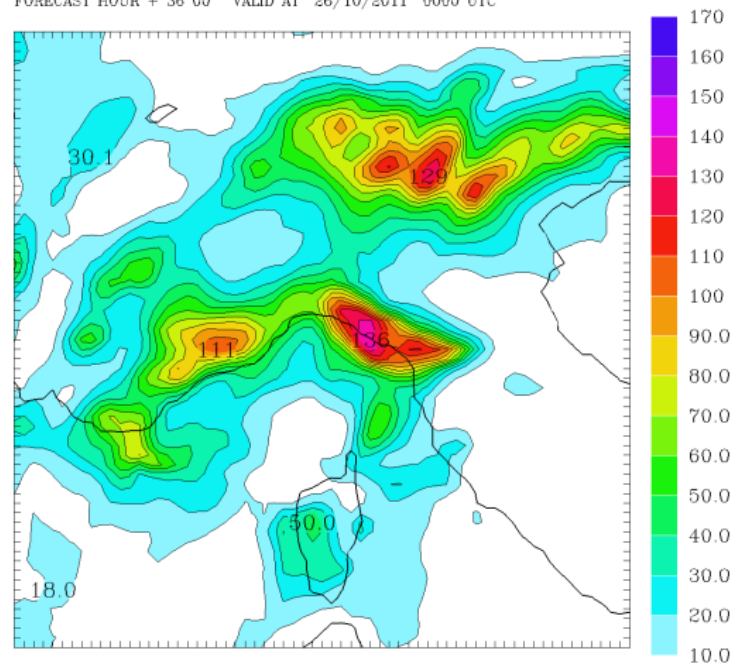

C

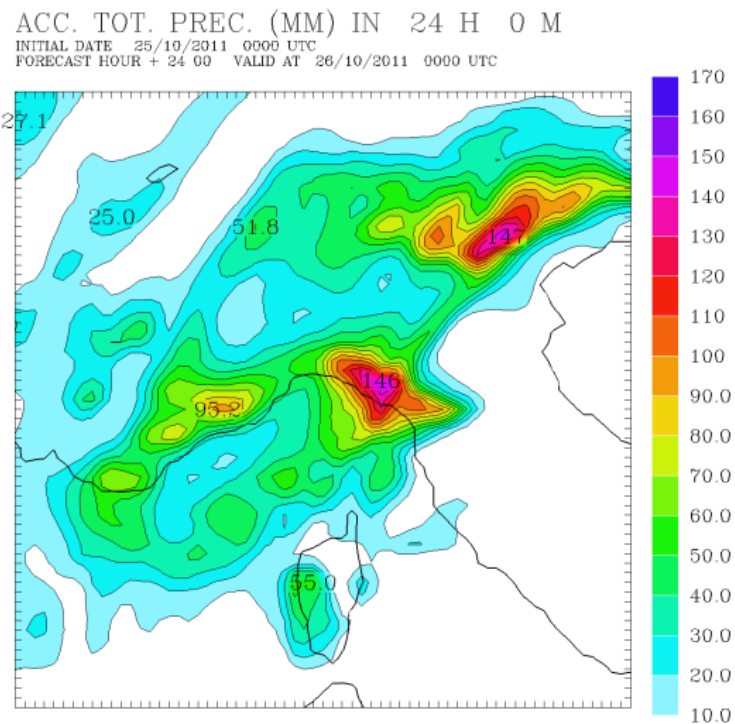

b

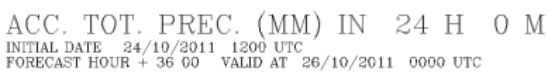

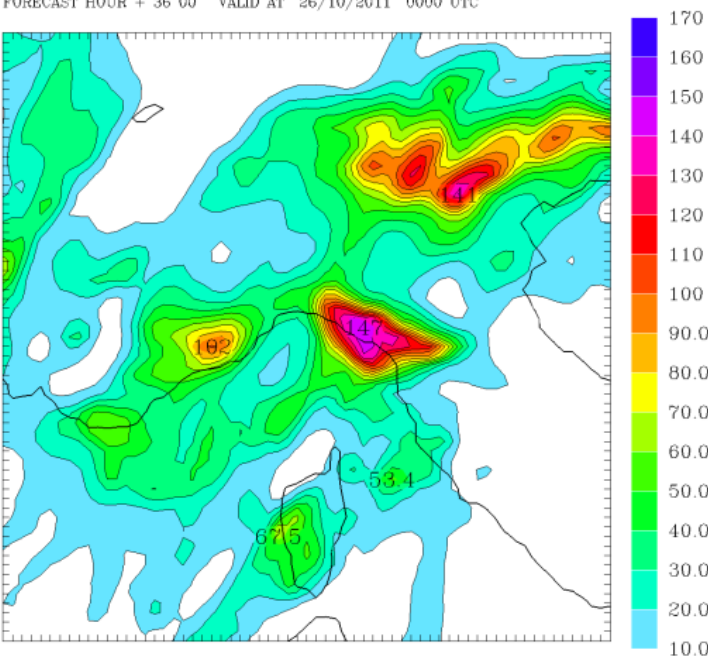

d

ACC, TOT. PREC. (MM) IN 24 H 0 M
INITIAL DATE 25/10/2011 000 UTC
FORECAST HOUR +24 Do VALID AT $26 / 10 / 20110000$ UTC

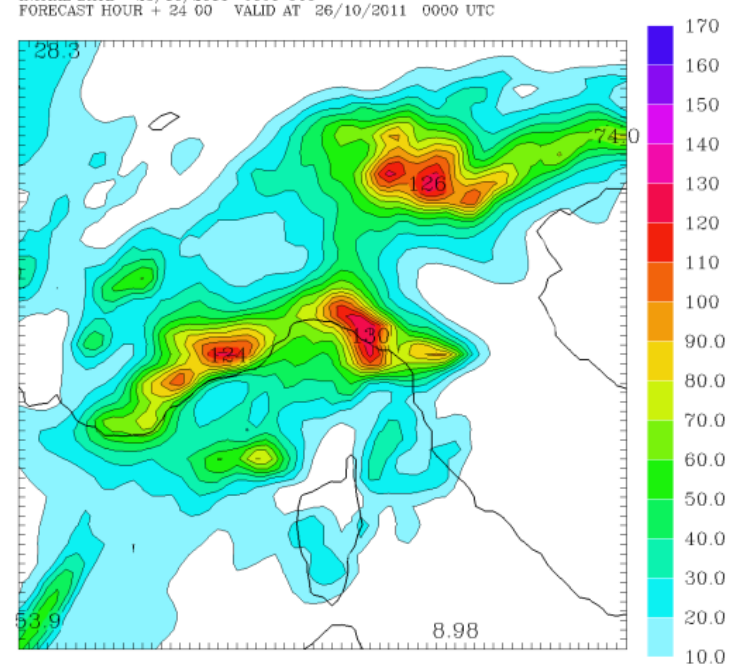

Figure 5. Precipitation accumulated in the $24 \mathrm{~h}$ period starting at 00:00 UTC of 25 October 2011 in BOLAM forecast runs based on ECMWFIFS (left column) and NOAA_GFS (right column) analyses. Upper panels: analyses of 12:00 UTC of 24 October; lower panels: analyses of 00:00 UTC of 25 October.

The BOLAM absolute maxima values over the Cinque Terre are reported for better clarity in Table 1: values range from 130 to $147 \mathrm{~mm} / 24 \mathrm{~h}$, while the fraction of model convective precipitation contributing to the maxima ranges from 62 to $88 \%$. This indicates on one side that convection is dominant, but, on the other side, that QPF is definitely underestimated by the BOLAM model if compared with the observed maxima that locally exceeded by three times the predicted values (see Fig. 2).
Regarding the GE event, Fig. 6 shows that a concentrated precipitation maximum near Genoa is predictable even with an hydrostatic, mid-resolution model (compare with Fig. 3). However, a closer inspection of the figures indicates that such a precipitation maximum is located, in all runs, about $30 \mathrm{~km}$ to the west of the observed maximum. Moreover, the time evolution indicates that most of the contributing rainfall occurs in the second half of the day, while in reality it was observed in the late morning. Simulated maxima in this case (see Table 2) range from 174 to $220 \mathrm{~mm} / 24 \mathrm{~h}$, while the 
a

ACC. TOT. PREC. (MM) IN 24 H 0 M
INITIAL DATE O3/11/2011 1200 UTC
FORECAST HOUR +36 00 VALID AT $05 / 11 / 20110000$ UTC
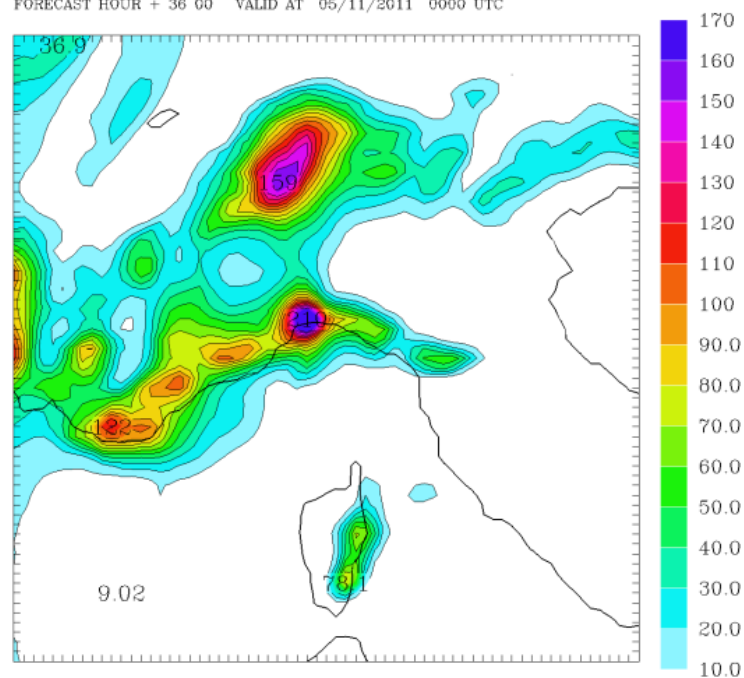

$\mathrm{c}$

ACC. TOT. PREC. (MM) IN 24 H 0 M
INITIAL DATE 04/11/2011 0000 UTC
FORECAST HOUR +24 00 VALID AT $05 / 11 / 20110000$ UTC

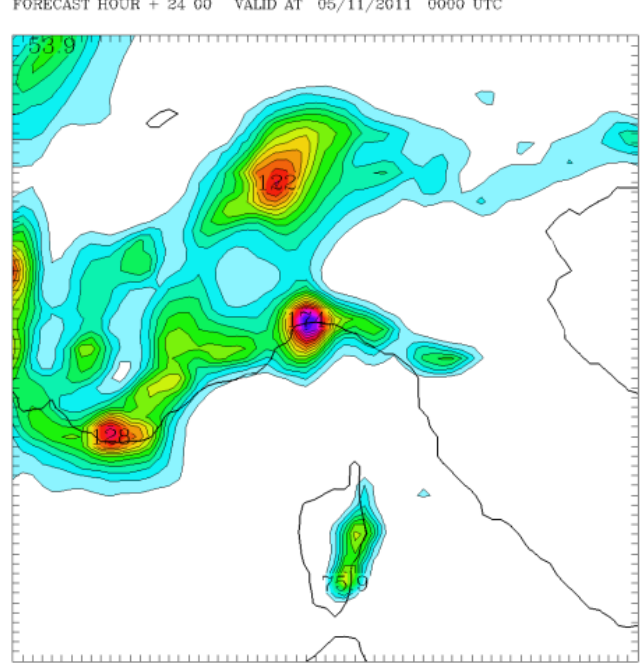

b

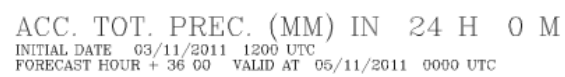

INTTAL DATE $03 / 11 / 2011$ 1200 UTC
FORECAST HOUR +3600 VALID AT $05 / 11 / 2011 \quad 0000$ UTC

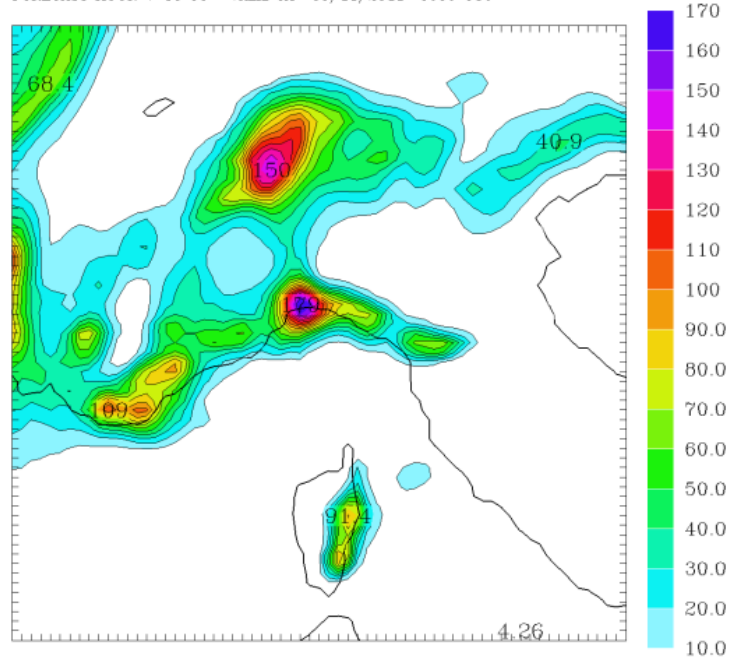

d

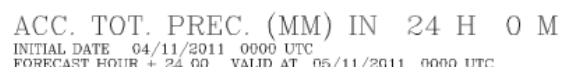

INITIAL DATE $04 / 11 / 2011$ 0000 UTC
FORECAST HOUR +24 Do

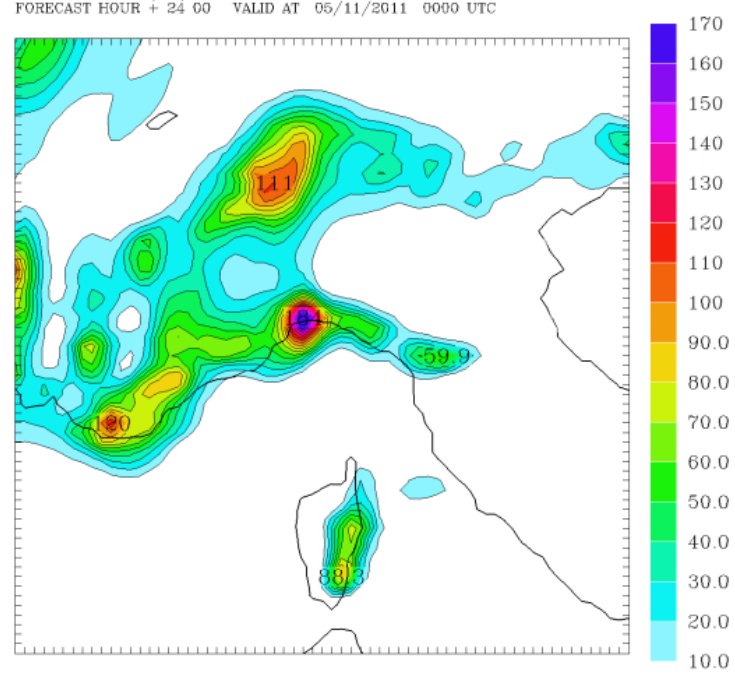

Figure 6. Precipitation accumulated in the $24 \mathrm{~h}$ period starting at 00:00 UTC of 4 November 2011 in BOLAM forecast runs based on ECMWF-IFS (left column) and NOAA_GFS (right column) analyses. Upper panels: analyses of 12:00 UTC of 3 November; lower panels: analyses of 00:00 UTC of 4 November.

convective component is $60 \%$ or less, that is smaller than in the CT case.

\subsection{MOLOCH model results}

MOLOCH-based forecast runs have been generated by embedding the grid domain into all the BOLAM runs described in Sect. 4.1. Different MOLOCH domain areas and horizon- tal resolutions have been tested, but since here we are interested mainly in discussing the effect of varying resolution, we have chosen to show only the results obtained with the largest MOLOCH grid, as specified in Sect. 3.3 (Fig. 1). Since the inner grid extension may affect the QPF results, a wide enough domain has been chosen in order to keep the influence of the lateral boundaries far away from the area of interest. In addition, the results are also dependent on the 
Table 1. Absolute maxima of precipitation in the BOLAM runs, for the CT event, corresponding to the initial conditions listed in the left column. The percentage of convective precipitation contributing to the maxima is reported in the right column (in parentheses).

\begin{tabular}{ll}
\hline Initial analysis & $\begin{array}{l}24 \mathrm{~h} \text { accumulated } \\
\text { precipitation }(\mathrm{mm}), \\
25 \text { October } 2011\end{array}$ \\
\hline ECMWF-IFS, 20111024, 12:00 UTC & $136(88 \%$ conv. $)$ \\
NOAA-GFS, 20111024, 12:00 UTC & $147(84 \%$ conv. $)$ \\
ECMWF-IFS, 20111025, 00:00 UTC & $146(63 \%$ conv $)$ \\
NOAA-GFS, 20111025, 00:00 UTC & $130(85 \%$ conv. $)$ \\
\hline
\end{tabular}

Table 2. As Table 1 but for the GE event.

\begin{tabular}{ll}
\hline Initial analysis & $\begin{array}{l}24 \mathrm{~h} \text { accumulated } \\
\text { precipitation }(\mathrm{mm}), \\
4 \text { November } 2011\end{array}$ \\
\hline ECMWF-IFS, 20111103, 12:00 UTC & $210(57 \%$ conv. $)$ \\
NOAA-GFS, 20111103, 12:00 UTC & $179(58 \%$ conv. $)$ \\
ECMWF-IFS, 20111104, 00:00 UTC & $174(55 \%$ conv. $)$ \\
NOAA-GFS, 20111104, 00:00 UTC & $184(60 \%$ conv. $)$ \\
\hline
\end{tabular}

arbitrary choice of the time of the initial condition for the MOLOCH model runs embedded in the BOLAM grid. We have decided, for the experiments presented here, to initiate the MOLOCH runs at 18:00 UTC in the case of BOLAM starting from the analysis at 12:00 UTC of the day preceding the event. In the case of 00:00 UTC analyses, the CT (GE) MOLOCH runs start at 03:00 (01:00) UTC, respectively.

In general, as expected, the latest analysis times chosen (namely 00:00 UTC of the same day of the events) gave the best results in terms of precipitation maximum amounts and localisation.

Tables 3 and 4 provide values of precipitation maxima obtained from the MOLOCH model having a grid spacing of $1.5 \mathrm{~km}$, for the cases of $\mathrm{CT}$ and GE, respectively. In the CT case (Table 3) precipitation maxima are larger for the NOAAGFS analysis, especially starting at 12:00 UTC of 24 October, but in the latter case the position of the most intense precipitation is too far north of the coast, being located near the divide of the Apennine chain in the area of Cinque Terre. In this respect (position error), the ECMWF-based run starting at 00:00 UTC of 25 October provides the most accurate result, although the maximum value $(216 \mathrm{~mm})$ is only about one half of the observed one. In the GE case (Table 4) it is clear that the forecast started from both global analyses of 3 November 12:00 UTC give too little precipitation. Moreover, the actual maxima, similarly to what occurs for BOLAM and for all cases (see Fig. 6), are located too far to the west of the observed position (Fig. 3). However, starting $12 \mathrm{~h}$ later, both analyses produce more satisfactory results in terms of amount as well as localisation of the precipitation peaks,
Table 3. Maxima of precipitation in the MOLOCH $1.5 \mathrm{~km}$ runs, for the CT event. Initial conditions (for BOLAM) are listed in the left column.

\begin{tabular}{lc}
\hline Initial & $\begin{array}{c}18 \mathrm{~h} \text { accumulated } \\
\text { analysis }\end{array}$ \\
& $\begin{array}{c}\text { 25 October 2011, } \\
\text { 06:00-24:00 UTC }\end{array}$ \\
\hline ECMWF-IFS, 20111024, 12:00 UTC & 289 \\
NOAA-GFS, 20111024, 12:00 UTC & 335 \\
ECMWF-IFS, 20111025, 00:00 UTC & 216 \\
NOAA-GFS, 20111025, 00:00 UTC & 318 \\
\hline
\end{tabular}

Table 4. As Table 3 but for the GE event.

\begin{tabular}{lc}
\hline $\begin{array}{l}\text { Initial } \\
\text { analysis }\end{array}$ & $\begin{array}{c}\text { 18 h accumulated } \\
\text { precipitation }(\mathrm{mm}), \\
\text { 4 November 2011, } \\
\text { 03:00-21:00 UTC }\end{array}$ \\
\hline ECMWF-IFS, 20111024, 12:00 UTC & 190 \\
NOAA-GFS, 20111024, 12:00 UTC & 140 \\
ECMWF-IFS, 20111025, 00:00 UTC & 266 \\
NOAA-GFS, 20111025, 00:00 UTC & 248 \\
\hline
\end{tabular}

although the observed precipitation still largely exceeds the simulated one, at least at the $1.5 \mathrm{~km}$ mesh size.

By comparing the ECMWF-IFS and the NOAA-GFS derived runs, it can be seen that, although differences in QPF are smaller than those due to different analysis times, the NOOA-GFS (ECMWF-IFS) analysis give better results, both in terms of precipitation maxima and location, in the CT (GE) case. Therefore, in the following of this section, we shall describe only the results obtained with MOLOCH at different resolutions and with the 00:00 UTC analyses.

\subsubsection{Cinque Terre (CT) case}

Figure 7 shows the accumulated precipitation (06:00 to 24:00 UTC of 25 October) as a function of MOLOCH horizontal grid spacing, for the run starting from NOAA-GFS analysis. Precipitation maxima tend to grow with increasing resolution up to $1.5 \mathrm{~km}$ grid distance. Moreover, in the case of the 2.0 and $1.5 \mathrm{~km}$ mesh sizes, the position of the two elongated main precipitation areas coincide well with the observed maxima (Fig. 2) over Cinque Terre and northern Tuscany, although in the case of $2 \mathrm{~km}$ the amount of simulated precipitation near the coast of Cinque Terre is far too small. Therefore, only if a forecast is made using a model mesh size of the order of or smaller than $1.5 \mathrm{~km}$, can it be considered sufficiently realistic to be used directly to produce a flood alert, although the observed precipitation (more than $500 \mathrm{~mm}$ ) still largely exceeds that predicted (about $320 \mathrm{~mm}$ ). In the case of $1 \mathrm{~km}$ mesh size (Fig. 7d), the convective cells contributing to the accumulated precipitation become 
a

ACC. TOT. PREC. (MM) IN $18 \mathrm{H} 0 \mathrm{M}$ INITAL DATE $25 / 10 / 2011$ O300 UTC
FORECAST HOUR +21 00 VALID AT $26 / 10 / 20110000$ UTC
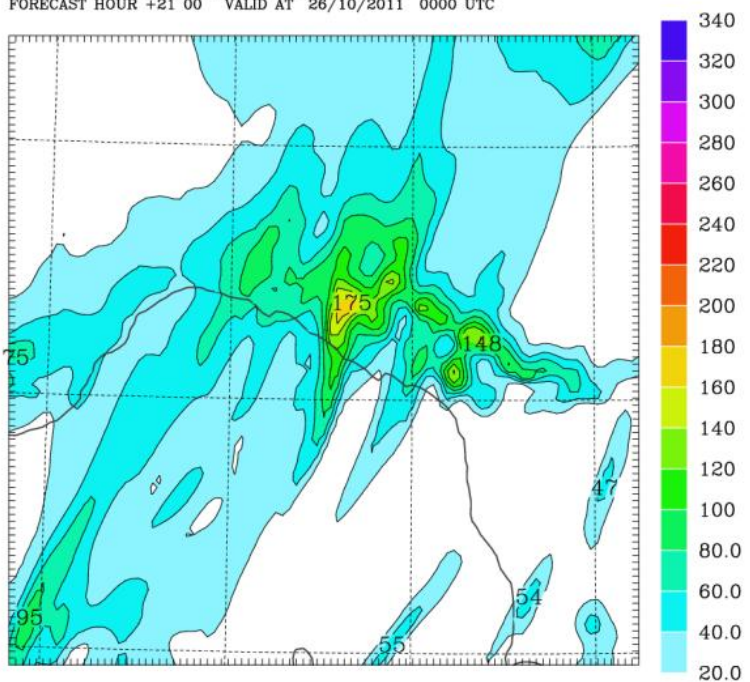

C

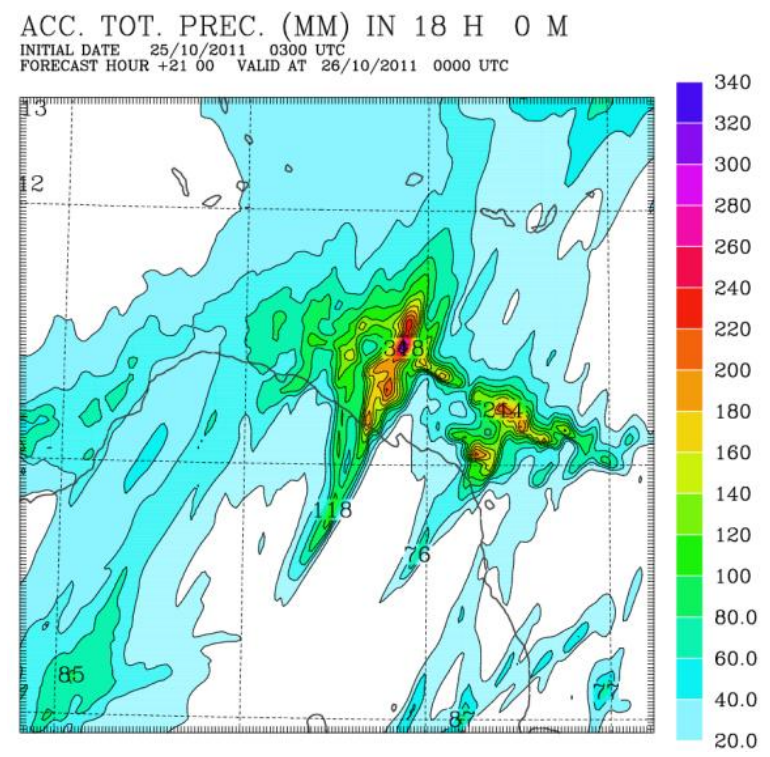

b

ACC. TOT. PREC. (MM) IN $18 \mathrm{H} 0 \mathrm{M}$ INITAL DATE $25 / 10 / 20110300$ UTC
FORECAST HOUR +21 00 VALLD AT $26 / 10 / 20110000$ UTC

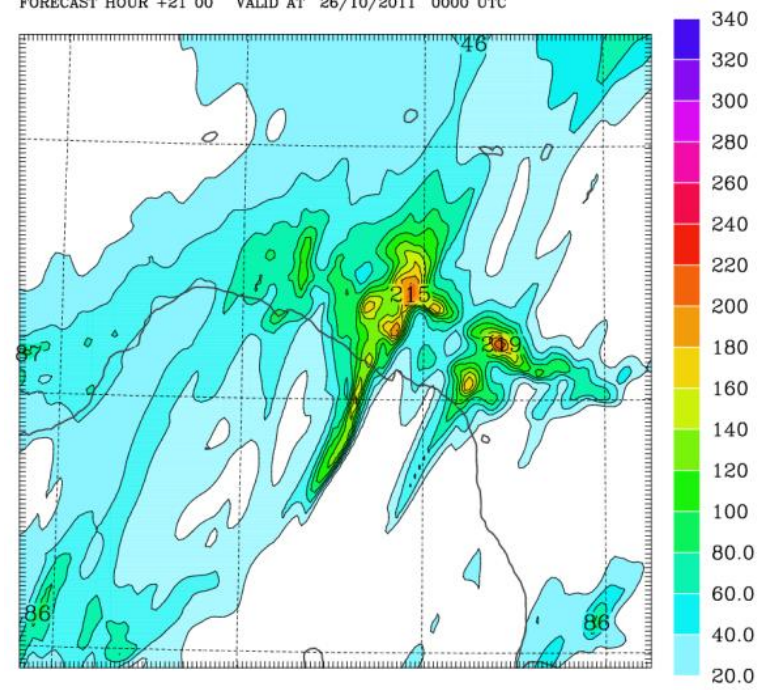

d

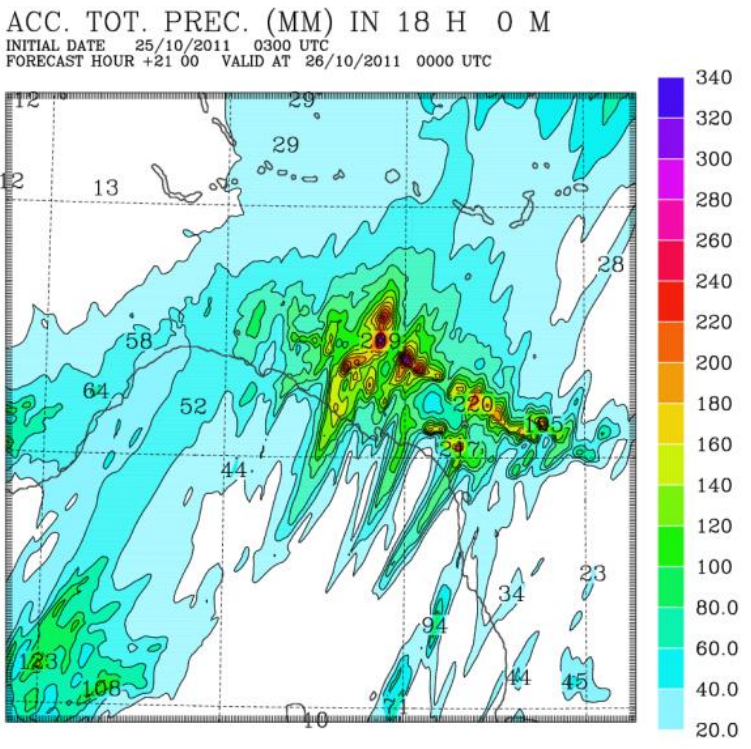

Figure 7. Precipitation accumulated in the $18 \mathrm{~h}$ period starting at 06:00 UTC of 25 October 2011 in MOLOCH forecast runs, based on NOAA-GFS analysis at 00:00 UTC of the same day, for different grid mesh sizes: $3.0 \mathrm{~km}$, max. $175 \mathrm{~mm}(\mathbf{a}), 2.0 \mathrm{~km}, 215 \mathrm{~mm}(\mathbf{b}), 1.5 \mathrm{~km}$, $318 \mathrm{~mm}(\mathbf{c}), 1.0 \mathrm{~km}, 299 \mathrm{~mm}(\mathbf{d})$. Contour interval: $20 \mathrm{~mm}$.

more scattered, giving less compact structures and therefore a slightly smaller absolute maximum (about $300 \mathrm{~mm}$ ), in spite of the fact that the spatially integrated precipitation tends to be larger in the area of interest.

Figure 8 shows the same accumulated precipitation corresponding to the model setup of Fig. 7c, but starting from the ECMWF-IFS analysis of 00:00 UTC. The comparison of the two figures shows that the shape and position of heavy precipitation areas are similar, although the maximum of the Cinque Terre area is $216 \mathrm{~mm}$ (318 in the NOAA-GFS case), while higher precipitation is accumulated $(301 \mathrm{~mm})$ over northern Tuscany. In the ECMWF case, precipitation is generally larger upstream, over the Ligurian Sea. For the $1 \mathrm{~km}$ mesh size, the ECMWF-based run (not shown) is also 


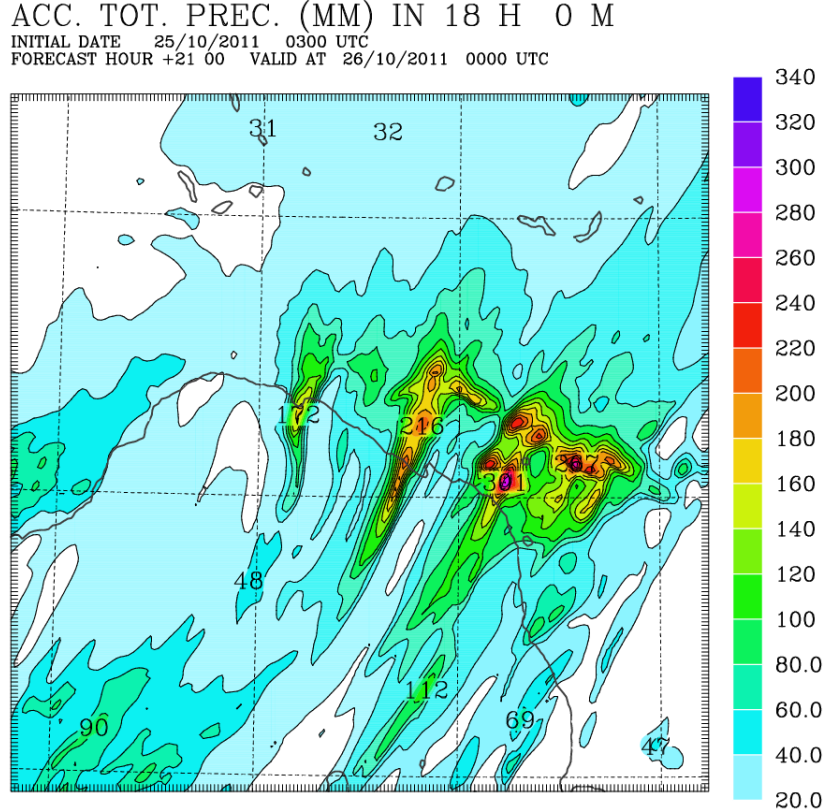

Figure 8. Same as Fig. 7c but for ECMWF-IFS analysis. Max. $301 \mathrm{~mm}$.

similar to the GFS-based run of Fig. 7d, showing more scattered precipitation. This suggests that the MOLOCH model in this case performs better at a horizontal grid spacing closer to 1.5 than $1 \mathrm{~km}$, but this result cannot be generalised, as indicated for example by the experiments described below for the second event.

\subsubsection{Genoa (GE) case}

Figure 9 shows the accumulated precipitation (03:00 to 21:00 UTC of 4 November) as a function of MOLOCH horizontal grid spacing, for the run starting from ECMWF-IFS analysis. In this case precipitation maxima grow monotonically, though not linearly, with the inverse of grid distance (the precipitation averaged over the area grows only slightly). For reference, the corresponding BOLAM precipitation (but accumulated in $24 \mathrm{~h}$ ) is given in Fig. 6c and in Table 2 (3rd row), while the observed distribution is shown in Fig. 3. Note that while at $3 \mathrm{~km}$ grid spacing the MOLOCH precipitation is only moderately higher than the BOLAM one, the position of the maximum that was observed in the eastern portion of the city of Genoa is very different between the two models and much more realistic in MOLOCH.

As resolution increases (Fig. 9a-d), the model precipitation maximum displaces eastward, so that in the case of $1 \mathrm{~km}$ grid size it is located very close to the observed one (Fig. 3 here and Fig. 14 of Retal), though still a couple of kilometres to the west of it. It should be recalled the both the observed and the simulated precipitating systems oscillated in longitude during the period of heavy rainfall. In spite of this, the main flood was related to the very high precipitation rates that affected a small area in the eastern portion of Genoa, as shown by the red symbols of Fig. 3. The secondary maximum visible in the same figure near the coast at about $1^{\circ}$ to the west of the primary maximum is related to precipitation that occurred late on the same day, after the surface convergence line had retreated rapidly to the west.

In this case, at variance with the previous one, both observations and simulations indicate that convection was initiated at about $50 \mathrm{~km}$ offshore, where the flow over the sea became convectively unstable (i.e. destabilised by possible lifting due to mesoscale convergence and/or orographic forcing). For this reason, the upstream flow in the GE case was more stable (in the sense that it exhibited less variability) than in the CT case in response to model or analysis changes. For example, the NOAA-based MOLOCH run at $1.0 \mathrm{~km}$ mesh size, shown in Fig. 10, produced a similar pattern and amount of precipitation compared with the corresponding ECMWF-based case (Fig. 9d).

\section{Results of model diagnostics}

The relevant mesoscale feature common to both events is the presence of a convergence line over the Ligurian Sea, intersecting the coast, due to simultaneous northerly cold outflow from the Po Valley and a southeasterly warm and unstable pre-frontal current. Such a feature, which has also been noted in other events (Lin et al., 2005) is clearly represented in the model simulations and has been verified in ASCAT observations (Retal). The shallow cold air flow derives from a preexisting cold air "reservoir" over the Po Valley and is not a manifestation of the synoptic-scale cold front. Such a flow is a rather frequent phenomenon of a katabatic wind over the slope of the Apennines between Genoa and the western part of Liguria, with local characteristics reminiscent, though less intense, of the Bora wind typical of the Adriatic eastern coast. The northerly outbreak of cold air towards the Ligurian Sea is generally associated with the thickening of low-level cold air in the western part of the Po Valley (surrounded on the western and northern sides by the Alps well exceeding $3000 \mathrm{~m}$ at the divide line), due to an easterly flow impinging from the eastern outlet of the valley. This easterly flow over the eastern Po Valley can either be associated with direct cold advection or, as in the cases considered here, with an easterly deviation (barrier wind), forced by the presence of the Alps, of a southerly or southeasterly wind over the Adriatic (Scirocco). In the latter case, the cold air over the Po Valley pre-exists the onset of the cold flow over the Gulf of Genoa. The simultaneous approaching of a depression from the west causes a pressure drop over the Ligurian Sea that is associated with the establishment of a south-to-north pressure gradient across the Apennines. This pressure gradient enhances the cold outflow from the Po Valley into the Gulf of Genoa. As noted above, the cold outflow was present in both episodes considered here and was more pronounced in the CT case. 
a

ACC. TOT. PREC. (MM) IN $18 \mathrm{H} \quad 0 \mathrm{M}$

$\begin{array}{llll}\text { INITIAL DATE } 04 / 11 / 2011 & 0100 \text { UTC } \\ \text { FORECAST HOUR +20 00 VALID AT } & 04 / 11 / 2011 & 2100 & \text { UTC }\end{array}$
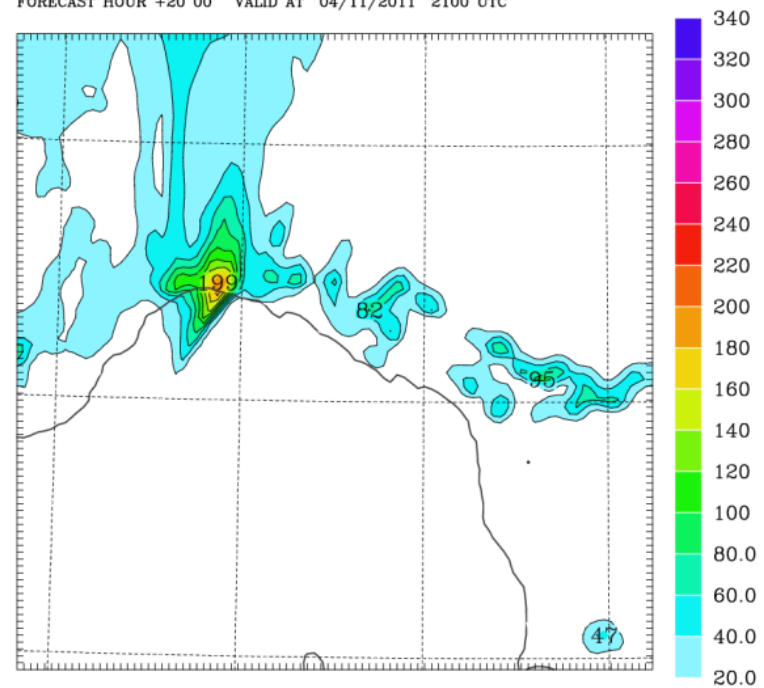

c

ACC. TOT. PREC. (MM) IN $18 \mathrm{H} \quad 0 \mathrm{M}$

INITIAL DATE $04 / 11 / 2011$ O100 UTC
FORECAST HOUR +20 00 VALID AT 04/11/2011 2100 UTC

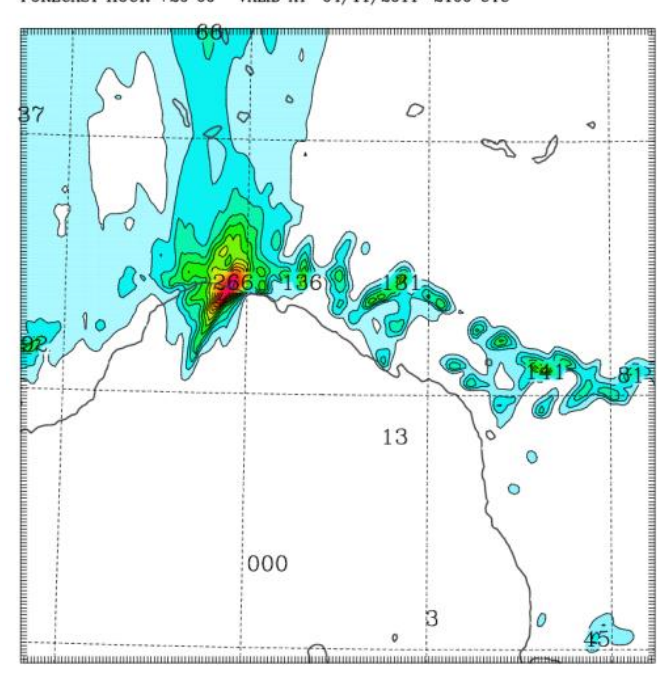

b

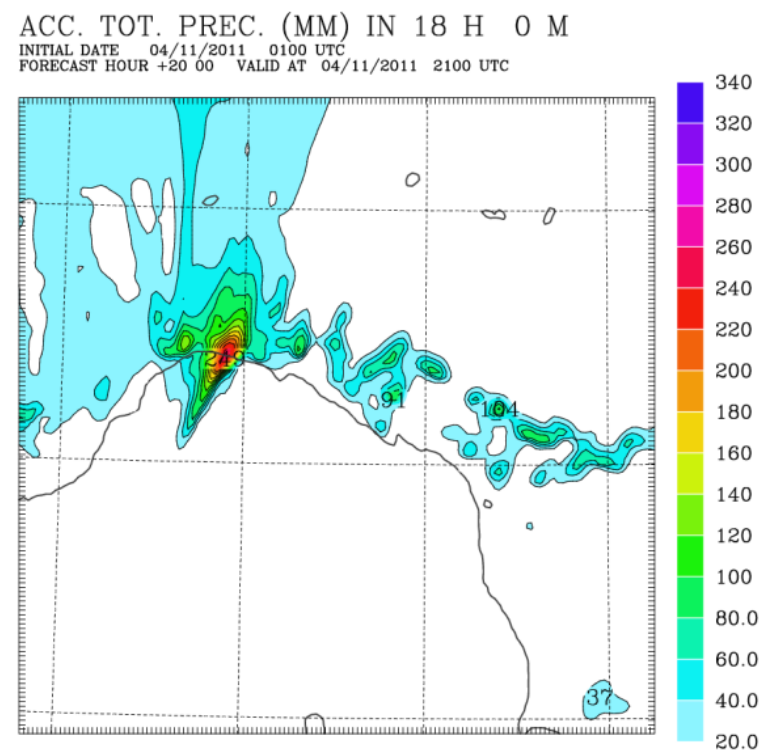

d

ACC. TOT. PREC. (MM) IN $18 \mathrm{H} \quad 0 \mathrm{M}$

INITAL DATE $04 / 11 / 2011$ o10 UTC
FORECAST HOUR + 20 O0 VALID AT $04 / 11 / 20112100$ UTC

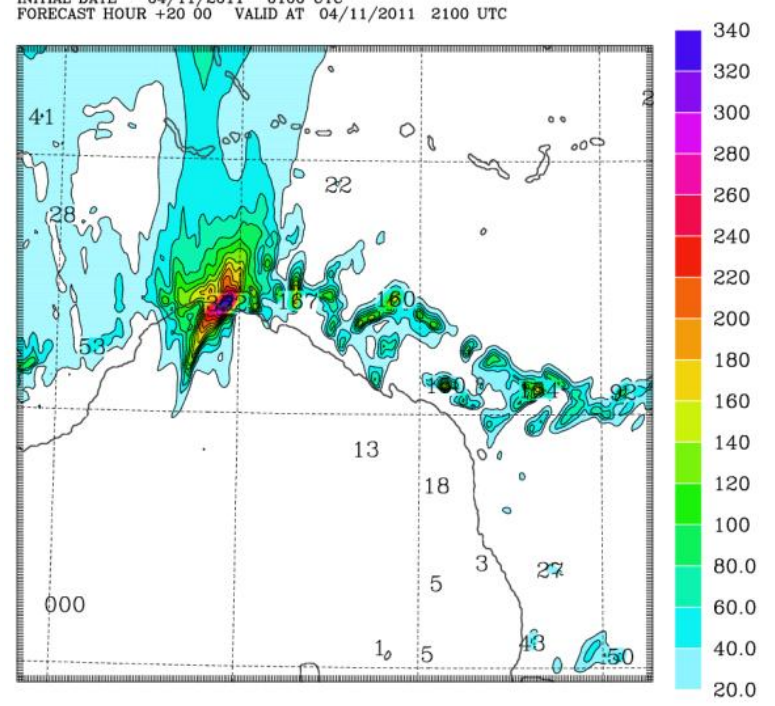

Figure 9. Precipitation accumulated in the $18 \mathrm{~h}$ period starting at 03:00 UTC of 4 November 2011 in MOLOCH forecast runs, based on ECMWF-IFS analysis at 00:00 UTC of the same day, for different grid mesh sizes: $3.0 \mathrm{~km}$, max. $199 \mathrm{~mm}(\mathbf{a}), 2.0 \mathrm{~km}, 249 \mathrm{~mm}(\mathbf{b}), 1.5 \mathrm{~km}$, $266 \mathrm{~mm}(\mathbf{c}), 1.0 \mathrm{~km}, 352 \mathrm{~mm}$ (d). Contour interval: $20 \mathrm{~mm}$.

The cross sections of Fig. 11 intersect the convergence line and show the effect of the descent of the cold air from the Apennines to the sea. Figure 11a shows the coherent strongest updraft responsible for the main precipitating system over the Cinque Terre region (to the east) and a secondary cell of rising motion (central part of the figure, in the prefrontal area - see also Fig. 12a and b) whose downdraft reinforces the leading edge of the cold density current.
Figure $11 \mathrm{~b}$ shows the distribution of condensate, which is upright in the main cell and slantwise in the secondary one.

Figure 12 illustrates the MOLOCH near-surface $(10 \mathrm{~m})$ wind, averaged over successive periods of 3 hours, and the corresponding precipitation, accumulated over the same time intervals, for CT (GE) in the left (right) columns of the figure. In both events, convergence lines in the $10 \mathrm{~m}$ wind can be clearly distinguished over the Ligurian Sea. The positions 


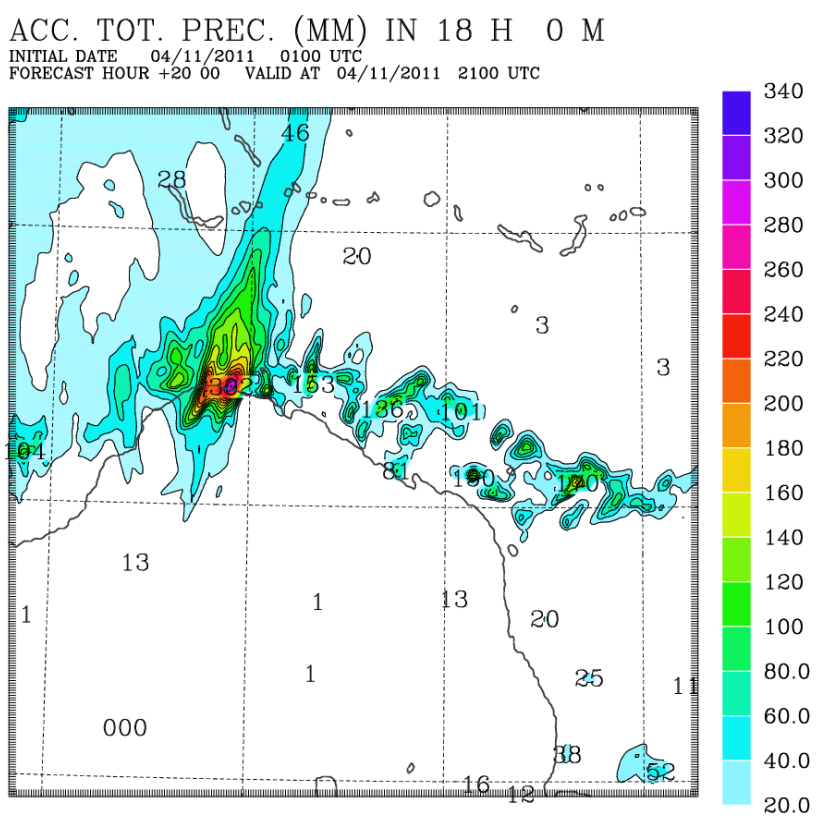

Figure 10. Same as Fig. 9d but for NOAA-GFS analysis. Max. $302 \mathrm{~mm}$.

of such lines closely correspond to the area of initiation of precipitation swaths, that is the area of initiation of convection, which develops further in the SW-NE direction and becomes severe over the orographic slope. Differences can be noted between the two cases, the main one being related to the evolution and displacement of the precipitating bands. In the $\mathrm{CT}$ event, the convergence line and the associated precipitation move slowly to the east and a secondary precipitation band is observed to the west of the most intense one, associated with the progression of the synoptic cold front, as mentioned above. In contrast, the GE event is characterised by a non-drifting, though oscillating, convergence and precipitation patterns, which remain near Genoa except in the final stage, when they move to the west. The relationship between the precipitation and the convergence line is even closer in this case, in which the convective system is located at the intersection between the edge of the cold pool and the coastline. In the GE case the synoptic cold front remains located to the west of the area represented in Fig. 12.

All the characteristics described in the above paragraph, revealing the close association between low-level convergence of the northerly cold flow with the warm conveyor belt (WCB) and convection, appear realistic if compared with observations. For example, the precipitation field of Fig. 12b can be compared with the observed radar reflectivity (Fig. 4, taken at the end of the accumulating period of Fig. 12b), which documents the presence of the main convective line and a secondary rainfall area to the west of it.

The different precipitation regimes exhibited by the CT and GE cases, shown in Fig. 12, are related to the stability properties of the southeasterly flow impinging on the con-
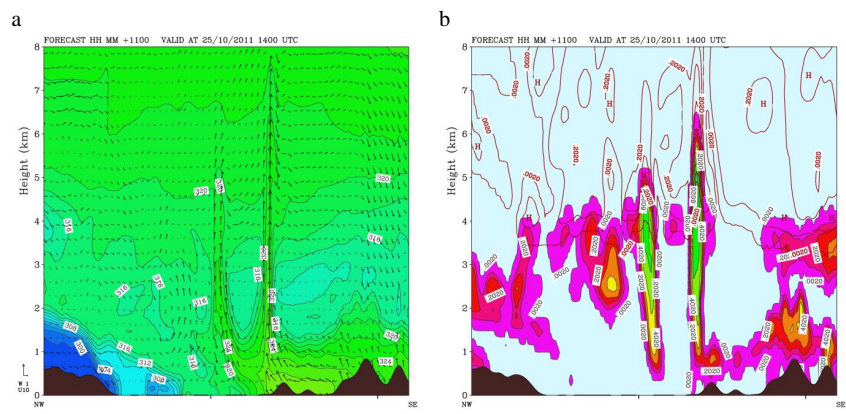

Figure 11. Cross sections taken along the segment shown in Fig. 1, for the CT event at 14:00 UTC of 25 October. (a) equivalent potential temperature and tangent flow component; (b) cloud water (coloured, contour interval $0.1 \mathrm{~g} \mathrm{~kg}^{-1}$ ) and cloud ice (solid contours, same interval).

vergence line. The CAPE carried by such a flow is similar in both cases (in the range of $500-1200 \mathrm{~J} \mathrm{~kg}^{-1}$, not shown), being only slightly larger in the CT event. However, a clear distinction between the two cases can be obtained by considering the buoyancy of vertically displaced air parcels, a property more linked to "quasi-linear" stability. Figure 13 reports the virtual temperature difference (including the loading of condensed water) between an air parcel raised by a given displacement and the environmental air as a function of the height of the parcel itself, for CT (red) and GE (blue) events. The vertical lift considered here $(500 \mathrm{~m})$ is consistent with the height of the leading edge of the density current, which determines the initial uplift of air parcels carried by the southeasterly flow (see Fig. 11a). The initial properties of air parcels are computed by averaging the southeasterly flow over two areas, upstream of precipitation, centred on the locations shown in Fig. 12b and e for the CT and GE cases, respectively. It can be seen that in the CT event the lowest layer of depth of roughly $1 \mathrm{~km}$ is unstable with respect to small vertical displacements. This result, obtained by assuming entropy conservation of a mixture of air/vapour/cloud water, is verified for a range of vertical displacements (from 300 to $800 \mathrm{~m}$ ), small enough to assume that condensed water is retained by the lifted parcel. In the GE event only a large vertical lift of low-level parcels can account for instability, since the level of free convection is estimated, from an upstream model-derived sounding (not shown), to be around $1500 \mathrm{~m}$. However, the lowest layer of $1.4 \mathrm{~km}$ depth is potentially unstable when raised as a whole, its top being cooled (roughly) $2.0^{\circ}$ more than its base in an environment with quasi uniform equivalent potential temperature. It is noteworthy that a huge amount of precipitation was actually achieved in this situation. 

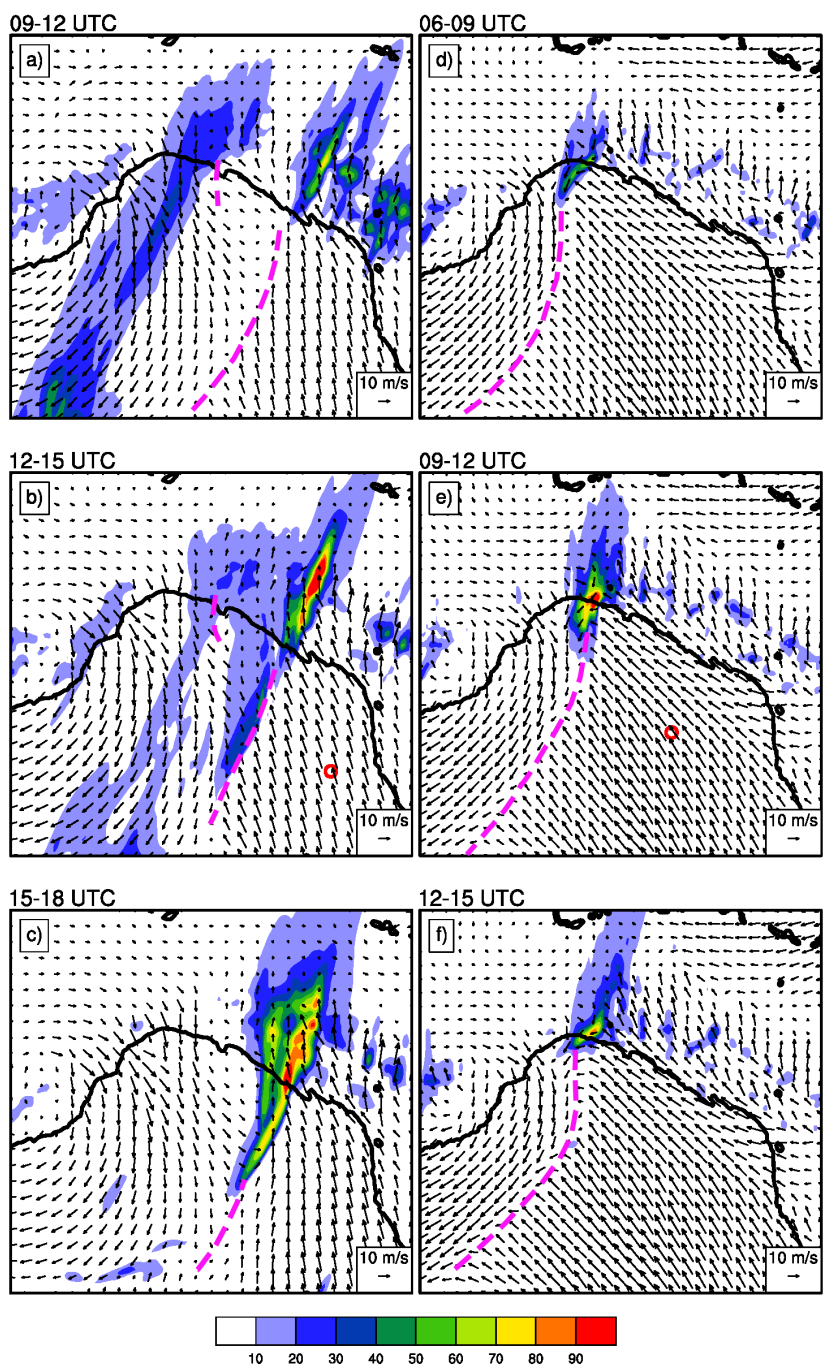

Figure 12. Precipitation accumulated every $3 \mathrm{~h}$ and $10 \mathrm{~m}$ wind averaged over the same interval, for MOLOCH forecasts. Left column: the CT case, run at $1.5 \mathrm{~km}$ mesh size, starting from NOAA-GFS analysis at 00:00 UTC of 25 October 2011. Right column: the GE case, run at $1.0 \mathrm{~km}$ mesh size, starting from ECMWF-IFS analysis at 00:00 UTC of 4 November 2011. The purple dotted lines mark the convergence lines. For the small red circles in (b) and (e), see the captions of Fig. 13.

\section{Summary and conclusions}

In this work, two events of intense precipitation and flash floods that occurred in the Liguria region during the days of 25 October (CT) and 4 November (GE) 2011 have been simulated in forecast mode using the BOLAM and MOLOCH models. Initial and boundary conditions for the numerical experiments have been obtained from ECMWF-IFS and NOAA-GFS global forecasts starting at 12:00 UTC of 24 October and 00:00 UTC of 25 October for the first event, and 12:00 UTC of 3 November and 00:00 UTC of 4 November for the second one. In both cases, realistic simulations in
Tv Parcel - Tv Environment (vertical displacement 500m)

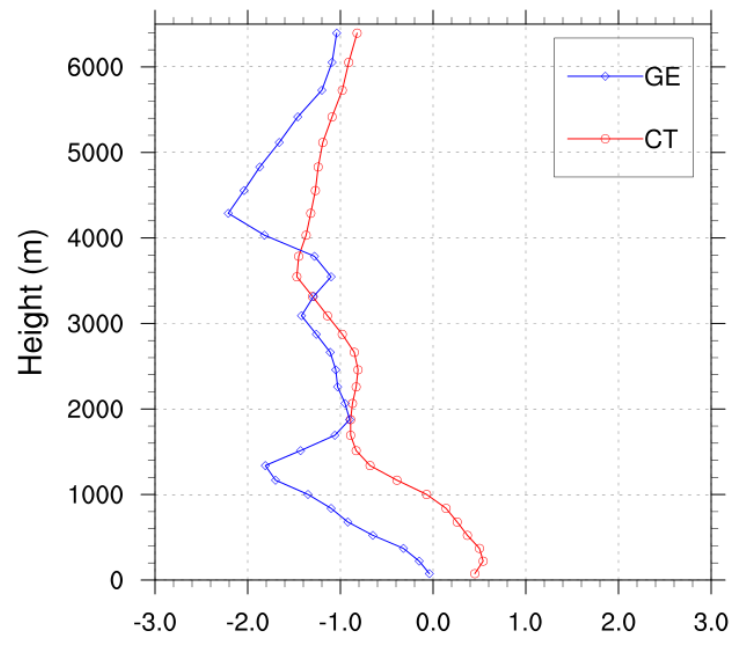

(K)

Figure 13. Profiles of virtual temperature difference between an air parcel raised to a height of $500 \mathrm{~m}$ above its initial position (vertical axis) and the environment at the final height, for the same experiments of Fig. 12. Red: CT case, valid at 12:00 UTC of 25 October, averaged in a square of $0.5^{\circ}$ side, centred at the small red circle in Fig. 12b. Blue: GE case, valid at 09:00 UTC of 4 November, centred at the small red circle in Fig. 12e.

terms of accumulated precipitation are obtained only with initial conditions closer to the events, namely at 00:00 UTC. For each event, the role of horizontal resolution has been investigated by running the MOLOCH convection-permitting model at 3.0, 2.0, 1.5, and $1.0 \mathrm{~km}$ grid spacing over both analysis data sets. In the GE case, IFS analysis gives the best results, with precipitation amounts and geographical localisation getting better and better with increasing resolution. In the CT case, slightly better results are obtained with $1.5 \mathrm{~km}$ grid spacing and GFS analysis. In general, timing and localisation of simulated precipitation is quite realistic, but precipitation maxima $(350 \mathrm{~mm}$ at most) are underestimated with respect to the exceptionally large observed values, of the order of $500 \mathrm{~mm}$ in $24 \mathrm{~h}$. QPF in this range is however critical for the prediction of flood situations.

All numerical simulations reveal the important role played by the low-level convergence of cold air flowing from the north downslope the Ligurian Apennines, and the warmer and moist southeasterly flow, which is associated with synoptic features, in determining the generation and subsequent development of convective cells near the coast and inland. In the GE event, the cold northerly flow is weaker and the impinging southerly flow less unstable than in the CT case. As a consequence, the simulated convection in GE is more organised and closely linked to the convergence line, being located just to the north of it in all instants. In the CT case, the leading edge of the cold outflow spreads more deeply over the sea, triggering convective cells, which subsequently amplify 
over the coast and the adjacent orographic slope. The crucial role played by this mesoscale convergence line can explain the extended range of predictability (with respect to the typical timescale of spontaneous convection) shown by these events, particularly the GE case.

In terms of spatial scales of motion involved in the occurrence of the severe convection, we can identify a synoptic (or meso-alpha) scale component (baroclinic wave trough, PV anomaly, upper jet, low-level jet represented by the WCB, synoptic fronts, etc.), a meso-beta scale, characterising the orographically induced flow (the density current contributing to the convergence line) and a meso-gamma scale constituted primarily by the convective cells and related precipitation patterns. There are different interaction processes among such different scales, the most complex being the feedback of the convection on the larger scale represented, for example, by the density current. It is well known that the formation of evaporative cold pools is crucial in determining the organisation, strength and propagation properties of the convective systems (Emanuel, 1994). In the cases considered here the formation of the cold pool precedes the onset of convection and sets up independently, due to orographic gap outflow. Once the convection has developed its own downdraft branch, it can modify and reinforce the pre-existing low-level cold flow. In order to explore this aspect, a number of sensitivity experiments were run that are not presented here. Such experiments indicate that evaporation of precipitation influences to some extent the propagation and hence the position of the convection in both cases, favouring the stationarity of the systems in the stage of the heaviest precipitation. In this respect, evaporation contributes to a more accurate QPF. This, together with the more accurate representation of orography, can explain why high resolution simulates more precipitation associated with stronger vertical motions, but also better forecasting of the position of the convective systems. In conclusion, we can say that for both episodes, though to a different extent, the localised triggering due to the convergence line, in association with the topographic forcing, accounts for the predictability that is apparently larger than what can be expected in the presence of deep convection.

Acknowledgements. We thank Christian Barthlott and another (anonymous) referee for their valuable suggestions, and Marcello Miglietta for his comments. This work was supported by the Civil Protection of Italy under contract "Intesa Operativa con CNRISAC". The authors thank Chiara Marsigli of ARPA-SIMC for the rain gauge data. Radar data were provided by Regione Liguria. This work is a contribution to the HyMeX international programme.

Edited by: C. Ramis

Reviewed by: C. Barthlott and one anonymous referee

\section{References}

Bertò, A., Buzzi, A., and Zardi, D.: A warm conveyor belt mechanism accompanying extreme precipitation events over northeastern Italy, Croat. Meteorol. J., 40, 338-341, 2005.

Billet, S. and Toro, E. F.: On WAF-type schemes for multidimensional hyperbolic conservation laws, J. Comput. Phys., 130, 124, 1997.

Bougeault, P., and Lacarrere, P.: Parameterization of orographyinduced turbulence in a mesoscale model. Mon. Wea. Rev., 117, 1872-1890, 1989.

Buzzi, A., Fantini, M., Malguzzi, P., and Nerozzi, F.,: Validation of a limited area model in cases of Mediterranean cyclogenesis: surface fields and precipitation scores, Meteorol. Atmos. Phys., 53, 137-153, 1994.

Buzzi, A., D'Isidoro, M., and Davolio, S.: A case study of an orographic cyclone south of the Alps during the MAP SOP, Q. J. Roy. Meteor. Soc., 129, 1795-1818, 2003.

Carlson, T. N.: Airflow through midlatitude cyclones and the comma cloud pattern, Mon. Weather Rev., 108, 1498-1509, 1980.

Charnock, H.: Wind stress over a water surface, Q. J. Roy. Meteor. Soc., 81, 639-640, 1955.

Davolio, S., Buzzi, A., and Malguzzi, P.: Orographic influence on deep convection: case study and sensitivity experiments, Meteorol. Z., 15, 215-223, 2006.

Davolio, S., Buzzi, A., and Malguzzi, P.: Orographic triggering of long-lived convection in three dimensions, Meteorol. Atmos. Phys., 103, 35-44, 2009a.

Davolio, S., Mastrangelo, D., Miglietta, M. M., Drofa, O., Buzzi, A., and Malguzzi, P.: High resolution simulations of a flash flood near Venice, Nat. Hazards Earth Syst. Sci., 9, 1671-1678, doi:10.5194/nhess-9-1671-2009, 2009b.

Davolio, S., Buzzi, A., Malguzzi, P., Mastrangelo, D., Laviola, S., Levizzani, V., Lighezzolo, A., and Munoz, E.: Analyses of heavy precipitation events over Ligurian region. Congreso Argentino de Teledeteccion 2012, 18-21 September 2012, Cordoba, Argentina, available at: http://www.isac.cnr.it/dinamica/ davolio/Paper/2012-CAT_Davolio_etal.pdf, 2012.

Deardorff, J. W.: Stratocumulus-capped mixed layers derived from a three dimensional model, Bound.-Lay.-Meteorol., 18, 495-527, 1980.

Diomede, T., Davolio, S., Marsigli, C., Miglietta, M. M., Moscatello, A., Papetti, P., Paccagnella, T., Buzzi, A., and Malguzzi, P.: Discharge prediction based on multi-model precipitation forecasts, Meteorol. Atmos. Phys., 101, 245-265, 2008.

Drobinski, P., Ducrocq, V., Alpert, P., Anagnostou, E., Béranger, K., Borga, M., Braud, I., Chanzy, A., Davolio, S., Delrieu, G., Estournel, C., Filali Boubrahmi, N., Font, J., Grubisic, V., Gualdi, S., Homar, V., Ivancan-Picek, B., Kottmeier, C., Kotroni, V., Lagouvardos, K., Lionello, P., Llasat, M. C., Ludwig, W., Lutoff, C., Mariotti, A., Richard, E., Romero, R., Rotunno, R., Roussot, O., Ruin, I., Somot, S., Taupier-Letage, I., Tintore, J., Uijlenhoet, R., and Wernli, H.: HyMeX, a 10-year multidisciplinary program on the Mediterranean water cycle, B. Am. Meteorol. Soc., in press doi:10.1175/BAMS-D-12-00242.1, 2014.

Drofa, O. V. and Malguzzi, P.: Parameterization of microphysical processes in a non hydrostatic prediction model, Proc. 14th Intern. Conf. on Clouds and Precipitation (ICCP), Bologna, 19-23 July 2004, 1297-3000, 2004. 
Ducrocq, V., Braud, I., Davolio, S., Ferretti, R., Flamant, C., Jansa, A., Kalthoff, N., Richard, E., Taupier-Letage, I., Ayral, P.-A., Belamari, S., Berne, A., Borga, M., Boudevillain, B., Bock, O., Boichard, J.-L., Bouin, M.-N., Bousquet, O., Bouvier, C., Chiggiato, J., Cimini, D., Corsmeier, U., Coppola, L., Cocquerez, P., Defer, E., Drobinski, P., Dufournet, Y., Fourrieì, N., Gourley, J. J., Labatut, L., Lambert, D., Le Coz, J., Marzano, F. S., Molinieì, G., Montani, A., Nord, G., Nuret, M., Ramage, K., Rison, B., Roussot, O., Said, F., Schwarzenboeck, A., Testor, P., Van Baelen, J., Vincendon, B., Aran, M., and Tamayo, J.: HyMeXSOP1, the field campaign dedicated to heavy precipitation and flash flooding in the northwestern Mediterranean, B. Am. Meteorol. Soc., in press, doi:10.1175/BAMS-D-12-00244.1, 2014.

Emanuel, K. A.: Atmospheric Convection. Oxford University Press, 580 pp., 1994.

Fantini, M., Malguzzi, P., and Buzzi, A.: Numerical study of slantwise circulations in a strongly-sheared pre-frontal environment, Q. J. Roy. Meteor. Soc., 138, 585-595, 2012.

Kain, J. S.: The Kain-Fritsch convective parameterization: an update, J. App. Meteorol., 43, 170-181, 2004.

Lin, Y.-L., Reeves, H. D., Chen, S.-Y., and Chiao, S.: Formation mechanisms for convection over the Ligurian Sea during MAP IOP-8, Mon. Weather Rev., 133, 2227-2245, 2005.

Malguzzi, P., Grossi, G., Buzzi, A., Ranzi, R., and Buizza, R.: The 1966 "century" flood in Italy: A meteorological and hydrological revisitation, J. Geophys. Res., 111, D24106, doi:10.1029/2006JD007111, 2006.

Marchi L., Boni, G., Cavalli, M., Comiti, F., Crema, S., Lucía, A., Marra, F., and Zoccatelli, D.: The Flash-flood of October 2011 in the Magra river (Italy): rainstorm characterization and flood response analysis, Geophys. Res. Abst., 15, EGU2013-11125, 2013.

Mlawer, E. J., Taubman, S. J.,. Brown, P. D., Iacono, M. J., and Clough, S. A.: Radiative transfer for inhomogeneous atmospheres: RRTM, a validated correlated-k model for the longwave. J. Geophys. Res., 102D, 16, 663-682, 1997.

Morcrette, J.-J., Barker, H. W., Cole, J. N. S., Iacono, M. J., and Pincus, R.: Impact of a new radiation package, McRad, in the ECMWF Integrated Forecasting System, Mon. Weather Rev., 136, 4773-4798, 2008.

Nuissier, O., Ducrocq, V., Ricard, D., Lebeaupin, C., and Anquetin, S.: A numerical study of three catastrophic precipitating events over southern France. I: Numerical framework and synoptic ingredients, Q. J. Roy. Meteor. Soc., 134, 111-130, 2008.

Ralph, F. M. and Dettinger, M. D.: Storms, floods, and the science of atmospheric rivers, EOS Trans. Am. Geophys. Un., 92, 265 266,2011
Ramis, C., Romero, R., and Homar, V.: The severe thunderstorm of 4 October 2007 in Mallorca: an observational study, Nat. Hazards Earth Syst. Sci., 9, 1237-1245, doi:10.5194/nhess-9-1237-2009, 2009.

Rebora, N., Molini, L., Casella, E., Comellas, A., Fiori, E., Pignone, F., Siccardi, F., Silvestro, F., Tanelli, S., and Parodi, A.: Extreme Rainfall in the Mediterranean: What Can We Learn from Observations?, J. Hydrometeorol., 14, 906-922, 2013.

Ricard, D., Ducrocq, V., and Auger, L.: A climatology of mesoscale environment associated with Mediterranean heavy precipitating events over northwestern Mediterranean area, J. Appl. Meteorol Clim., 51, 468-488, 2012

Richard, E., A. Buzzi, A., and Zängl, G.: Quantitative precipitation forecasting in mountainous regions: The advances achieved by the Mesoscale Alpine Programme, Q. J. Roy. Meteorol. Soc., 133, 831-846, 2007.

Ritter, B. and Geleyn, J. F.: A comprehensive radiation scheme for numerical weather prediction models with potential applications in climate simulations, Mon. Weather Rev., 120, 303-325, 1992.

Rotach, M. W., Ambrosetti, P., Ament, F., Appenzeller, C., Arpagaus, M., Bauer, H. S., Behrendt, A., Bouttier, F., Buzzi, A., Corazza, M., Davolio, S., Denhard, M., Dorninger, M., Fontannaz, L., Frick, J., Fundel, F., Germann, U., Gorgas, T., Hegg, C., Hering, A., Keil, C., Liniger, M. A., Marsigli, C., McTaggartCowan, R., Montani, A., Mylne, K., Ranzi, R., Richard, E., Rossa, A., Santos-Muñoz, D., Schär, C., Seity, Y., Staudinger, M., Stoll, M., Volkert, H., Walser, A., Wang, Y., Werhahn, J., Wulfmeyer, V., and Zappa, M.: MAP D-PHASE: Real-time Demonstration of Weather Forecast Quality in the Alpine Region, B. Am. Meteor. Soc., 90, 1321-1336, 2009.

Silvestro, F., Gabellani, S., Giannoni, F., Parodi, A., Rebora, N., Rudari, R., and Siccardi, F.: A hydrological analysis of the 4 November 2011 event in Genoa, Nat. Hazards Earth Syst. Sci., 12, 2743-2752, doi:10.5194/nhess-12-2743-2012, 2012.

Tibaldi, S., Buzzi, A., and Speranza, A.: Orographic cyclogenesis, in: The Palmen Memorial Volume, edited by: Newton, C. and Holopainen, E. O., Am. Meteorol. Soc., Boston, 107-127, 1990.

Turato, B., Reale, O., and Siccardi, F.: Water vapour sources of the October 2000 Piedmont flood. J. Hydrometeorol., 5, 693-712, 2004.

Zampieri, M.: Comparison among first, second and third order CBL model. The 6th Symposium on Boundary Layers and Turbulence, Portland, ME, 2004.

Zampieri, M., Malguzzi, P., and Buzzi, A.: Sensitivity of quantitative precipitation forecasts to boundary layer parameterization: a flash flood case study in the Western Mediterranean, Nat. Hazards Earth Syst. Sci., 5, 603-612, doi:10.5194/nhess-5-6032005, 2005. 